IZA DP No. 5558

Wars and Child Health:

Evidence from the Eritrean-Ethiopian Conflict

Richard Akresh

Leonardo Lucchetti

Harsha Thirumurthy

March 2011 


\title{
Wars and Child Health: Evidence from the Eritrean-Ethiopian Conflict
}

\author{
Richard Akresh \\ University of Illinois at Urbana-Champaign, \\ $B R E A D$ and IZA \\ Leonardo Lucchetti \\ University of Illinois at Urbana-Champaign \\ Harsha Thirumurthy \\ University of North Carolina at Chapel Hill, \\ World Bank and BREAD
}

\author{
Discussion Paper No. 5558 \\ March 2011
}

IZA

P.O. Box 7240

53072 Bonn

Germany

Phone: +49-228-3894-0

Fax: +49-228-3894-180

E-mail: iza@iza.org

\begin{abstract}
Any opinions expressed here are those of the author(s) and not those of IZA. Research published in this series may include views on policy, but the institute itself takes no institutional policy positions.

The Institute for the Study of Labor (IZA) in Bonn is a local and virtual international research center and a place of communication between science, politics and business. IZA is an independent nonprofit organization supported by Deutsche Post Foundation. The center is associated with the University of Bonn and offers a stimulating research environment through its international network, workshops and conferences, data service, project support, research visits and doctoral program. IZA engages in (i) original and internationally competitive research in all fields of labor economics, (ii) development of policy concepts, and (iii) dissemination of research results and concepts to the interested public.
\end{abstract}

IZA Discussion Papers often represent preliminary work and are circulated to encourage discussion. Citation of such a paper should account for its provisional character. A revised version may be available directly from the author. 
IZA Discussion Paper No. 5558

March 2011

\section{ABSTRACT \\ Wars and Child Health: Evidence from the Eritrean-Ethiopian Conflict ${ }^{\star}$}

This is the first paper using household survey data from two countries involved in an international war (Eritrea and Ethiopia) to measure the conflict's impact on children's health in both nations. The identification strategy uses event data to exploit exogenous variation in the conflict's geographic extent and timing and the exposure of different children's birth cohorts to the fighting. The paper uniquely incorporates GPS information on the distance between survey villages and conflict sites to more accurately measure a child's war exposure. Warexposed children in both countries have lower height-for-age Z-scores, with the children in the war-instigating and losing country (Eritrea) suffering more than the winning nation (Ethiopia). Negative impacts on boys and girls of being born during the conflict are comparable to impacts for children alive at the time of the war. Effects are robust to including region-specific time trends, alternative conflict exposure measures, and an instrumental variables strategy.

JEL Classification: I12, J13, O12

Keywords: child health, conflict, economic shocks, Africa

Corresponding author:

Richard Akresh

University of Illinois at Urbana-Champaign

Department of Economics

1407 West Gregory Drive

David Kinley Hall, Room 214

Urbana, IL 61801

USA

E-mail: akresh@illinois.edu

\footnotetext{
* We thank Mevlude Akbulut, llana Redstone Akresh, Laura Atuesta, Alfredo Burlando, Monserrat Bustelo, Dusan Paredes, Elizabeth Powers, and Mariano Rabassa for helpful comments and discussions on earlier drafts and Rafael Garduño-Rivera for help in generating the ArcGIS map in Figure 1.
} 


\section{Introduction}

Conditions experienced early in life or in utero have been shown to have persistent and long-

term effects on health, education, and socioeconomic outcomes (see seminal work by Stein et al. (1975) and more recent papers by Maccini and Yang (2009) and Maluccio et al. (2009)). Barker (1998) argues that health shocks suffered in utero can cause irreversible adaptations to the local food environment and that children cannot catch up even if they later have good nutrition and health care. Consequently, shocks that negatively impact a child's growth trajectory may lead to lower adult height, less cognitive ability and education, lower productivity and wages, and worse marital outcomes (see Strauss and Thomas (2008) for a review of the link between early childhood health and later life outcomes). Wars are one type of negative shock, and since World War II, armed conflict has affected three-fourths of all countries in sub-Saharan Africa (Gleditsch et al., 2002). In many instances, particularly in developing countries, the conflicts are started or are exacerbated by territorial disputes. ${ }^{1}$ Despite the casualties and destruction caused by wars, the impacts of conflict on health have received surprisingly limited focus in the literature, mainly due to data limitations, although that is changing recently (Alderman, Hoddinott, and Kinsey, 2006; Akbulut-Yuksel, 2009; Bundervoet, Verwimp, Akresh, 2009). ${ }^{2}$ In this paper, we examine the impact of exposure at birth or as a young child to an international war by estimating the subsequent effect on children's health status. We focus on the

\footnotetext{
${ }^{1}$ The United States Central Intelligence Agency World Factbook (2010) lists over 180 regions in the world that have existing disputes over international land or sea boundaries or have resource or resident disagreements; 41 of these disputes are in sub-Saharan Africa.

${ }^{2}$ Seminal work on conflict focuses on understanding the causes and spread of war and its role in reducing growth (Collier and Hoeffler, 1998; Miguel, Satyanath, and Sergenti, 2004; Guidolin and La Ferrara, 2007; Do and Iyer, 2010). The magnitude of conflict's long-term negative economic consequences are debated in the literature (see Davis and Weinstein (2002) for Japan; Brakman, Garretsen, and Schramm (2004) for Germany; Bellows and Miguel (2009) for Sierra Leone). There is also a growing literature examining the relationship between conflict and education outcomes (Ichino and Winter-Ebmer, 2004; Akresh and de Walque, 2008; Swee, 2009; Miguel and Roland, 2011; Shemyakina, 2011). Research focusing exclusively on soldiers finds large negative impacts on their earnings, and soldiers exposed to more violence face a harder time reintegrating into civilian society (Angrist, 1990; Imbens and van der Klaauw, 1995; Humphreys and Weinstein, 2007; Blattman and Annan, 2009).
} 
1998 to 2000 Eritrea-Ethiopia war that was based on a territorial border dispute. ${ }^{3}$ When Eritrea, formerly a province of Ethiopia, became independent in 1993 following a long guerrilla war, sections of the new border were never properly demarcated. Full-fledged fighting started in May 1998 over these areas, which have been described as desolate and inconsequential. Reporters have portrayed the Eritrea-Ethiopia war as having "echoes of World War One in its bloody stalemate and trench warfare” (GlobalSecurity.org, 2000). More than 300,000 troops were dug in and deadlocked on both sides of the border. Most of the conflict's casualties were soldiers, since most civilians left the war-torn areas, leaving the armies to fight over empty villages.

We make four main contributions to the literature examining the impacts of shocks on children's welfare. First, this is the first paper able to measure the welfare impacts for the two sides involved in a war, thereby providing a more comprehensive and robust understanding of how wars affect children's well-being. Second, we use multiple empirical identification strategies to measure the causal impact of war on child health. We combine data from nationally representative household surveys (2002 Eritrea and 2000 and 2005 Ethiopia Demographic and Health Surveys) with event data on the timing and geographic extent of the war to exploit the exogenous variation in children's birth cohorts that are exposed to the conflict. Further, to address potential measurement error in accurately capturing a child's war exposure that is often present when comparing large regions (parts of which experienced fighting and parts of which did not), we incorporate global positioning system (GPS) data on the distance between the survey villages and conflict sites. To verify that estimated health differences across regions and birth cohorts are due to the conflict, we incorporate direct measures of the number of displaced

\footnotetext{
${ }^{3}$ In the past 30 years, border wars were fought in Africa (Djibouti and Eritrea in 2008, Mauritania and Senegal starting in 1989, Burkina Faso and Mali in 1985, Ethiopia and Somalia in 1982), Asia (Cambodia and Thailand in 2008, India and Bangladesh in 2001, Israel and Lebanon starting in 2000, India and Pakistan in 1999, Thailand and Laos starting in 1987, India and China in 1987, Pakistan and India starting in 1984, Iran and Iraq starting in 1980, Vietnam and China starting in 1979), and South America (Ecuador and Peru in 1995, Ecuador and Peru in 1981).
} 
individuals from each region to proxy for the war's intensity in that area. Finally, because the war intensity variables are potentially measured with error or might be endogenous due to correlations with village or household level characteristics that influence child health, we instrument for these measures using GPS information on village location and distance to the war sites. Third, because of the fortuitous timing of the household survey data collection, we are able to explore how the effects of the shock differ for children born during the conflict compared to those born before the war started (and were subsequently young children at the time of the fighting). Fourth, the paper contributes to the study of gender bias in early childhood development and how that bias is affected differently by conflict shocks. Our separate estimation of the impact of war exposure for boys and girls finds that both suffer negative consequences of similar magnitude, contrasting with the existing literature. The contributions highlighted here are also the key differences between our paper and the most closed related prior work by Bundervoet, Verwimp, and Akresh (2009) who explore the impact of the Burundi civil war on child health. In particular, the multiple empirical identification strategies described earlier (GPS data, war intensity data, and instrumental variables strategy) address the shortcomings of the difference-in-differences approach used in the Burundi paper, leading to a more convincing causal estimate of war's impact on child health.

We find that war-exposed children in both countries have lower height-for-age Z-scores, and the negative impact is comparable for children born during or before the conflict. Both boys and girls experience significant negative impacts that are similar in magnitude as a result of war exposure. Results from our instrumented specification indicate that children born during the war and living in a region with the average number of internally displaced people have 0.77 or 0.31 standard deviations lower height-for-age Z-scores in Eritrea and Ethiopia, respectively. For 
children born before the war, these impacts are 0.89 and 0.41 standard deviations lower Z-scores, respectively. The results are robust to a number of alternative specifications that address issues of selective migration, potential misspecification of our geographic exposure variables, age misreporting, and selective mortality. Based on the existing early child development literature, the negative health impacts of the Eritrean-Ethiopian conflict are also likely to have long-run welfare impacts on war-exposed children.

Besides the previously discussed papers about impacts of shocks at birth, our results are related to research on gender bias during early childhood. Much of the literature finds evidence favoring boys over girls (see Rose (1999) for evidence from India that gender bias in infant mortality drops significantly when districts experience higher rainfall or Dercon and Krishnan (2000) for evidence from Ethiopia that poor households are unable to smooth their consumption, with women bearing the brunt of adverse shocks). However, in contrast to this literature, we find no differential gender impact of war on children's health, as both war-exposed boys and girls suffer negative consequences of similar magnitude.

The remainder of the paper is organized as follows. Section 2 provides an overview of the history of the Eritrea-Ethiopia conflict and sketches the spatial and temporal event data for the most recent war. Section 3 describes the survey data used in the analysis and explains the key variables. Section 4 describes the empirical identification strategy and Section 5 presents the main results as well as robustness tests. Section 6 concludes.

\section{Eritrean-Ethiopian War}

\subsection{History of Conflict and Independence of Eritrea}

The war between Eritrea and Ethiopia lasted two years beginning in 1998 and stemmed from a border dispute. Even before this war, the two countries had a long history of conflict with each 
other. The post-World War II period saw the former Italian colony of Eritrea become a region of Ethiopia, but growing dissatisfaction with the Ethiopian occupation led to a prolonged period of armed struggle by the Eritrean People’s Liberation Front (EPLF) against the Ethiopian Marxist government. The war against Ethiopia ended in 1991 and coincided with the end of the Ethiopian civil war in which a coalition of rebel groups - the Ethiopian People's Revolutionary Democratic Front (EPRDF) - overthrew the government and came to power under the leadership of Meles Zenawi. Following a referendum in Eritrea in May 1993, the sovereign state of Eritrea was formed with the EPLF leader Isaias Afwerki as President (EPLF was later renamed the People's Front for Democracy and Justice). The immediate period following Eritrean independence saw generally friendly relations between Eritrea and Ethiopia, in part because the governments had fought together against the previous Marxist government that formerly controlled Ethiopia.

At the time of Eritrean independence, both countries claimed sovereignty over three areas: Badme, Tsorona-Zalambessa, and Bure (see Figure 1 for a regional map of Eritrea and Ethiopia highlighting these three areas). Confusion over the border demarcation between the two countries was partially due to Ethiopia’s 1962 annexation of Eritrea, since at that time the former colonial boundaries were replaced by administrative boundaries within Ethiopia, some of which shifted slightly by 1993 (Global IDP Project, 2004b). A series of continued disputes in these three border areas combined with larger conflicts over trade and other economic issues, however, proved to be a major obstacle to maintaining peace. ${ }^{4}$

\subsection{Spatial and Temporal Intensity of the Eritrea-Ethiopia War}

In our analysis of child health, the exact timing and location of the fighting play a key role in our identification strategy. In May 1998, fighting broke out between Eritrean soldiers and Ethiopian

\footnotetext{
${ }^{4}$ Eritrea's independence in 1993 meant Ethiopia became a landlocked country, with implications for its trade and economic organization.
} 
militia and security police in the Badme area, which was under Ethiopian control. ${ }^{5}$ Within a week, the Ethiopian Parliament declared war on Eritrea, and all-out war ensued. Both countries devoted substantial resources to growing their armies, augmenting their military equipment, and fortifying their borders, which included digging extensive trenches. After the initial period of intense conflict, heavy fighting resumed in February 1999 as Ethiopia succeeded, despite high casualties, in retaking the border town of Badme, but the battles around Tsorona-Zalambessa were not conclusive. Both sides initially rejected efforts by regional groups to mediate an end to the conflict, but eventually a Cessation of Hostilities agreement was brokered on June 18, 2000 and a 25-kilometer-wide demilitarized Temporary Security Zone was established along the 1,000 kilometer Eritrea-Ethiopia border and patrolled by United Nations peacekeeping forces. A final comprehensive peace agreement was signed December 12, $2000 .^{6}$

The conflict intensity varied across regions within Ethiopia and Eritrea, with regions far from the border zones experiencing no fighting and the most intense clashes taking place in the border regions near Badme, Tsorona-Zalambessa, and Bure (see Figure 1). While there are not exact figures of the number of casualties due to the war, most estimates of the total number of fatalities, which were mainly soldiers, range from 70,000-100,000 (Human Rights Watch, 2003).

\subsection{Civilian Impacts of the War}

Although most casualties occurred among soldiers, thousands of civilians were displaced, which is the primary mechanism through which conflict may have affected child health. Displaced households suffered large reductions in food production, asset losses, and worsened access to

\footnotetext{
${ }^{5}$ The Eritrea Ethiopia Claims Commission (2005) states, “The areas initially invaded by Eritrean forces...were all either within undisputed Ethiopian territory or within territory that was peacefully administered by Ethiopia and that later would be on the Ethiopian side of the line to which Ethiopian armed forces were obligated to withdraw in 2000 under the Cease-Fire Agreement of June 18, 2000.”

${ }^{6}$ The empirical analysis in this paper treats this as the date the war ended, but our results are consistent if we treat June 2000, the date when the Cessation of Hostilities agreement was brokered, as the time when the war ended.
} 
water and health infrastructure. By the end of 1998, estimates suggest approximately 250,000 Eritreans had been internally displaced and another 45,000 Ethiopian citizens of Eritrean origin were deported from Ethiopia (Global IDP Project, 2004a). The Eritrean government and other observers estimate that during the war nearly 1.1 million Eritreans were internally displaced, although this number declined substantially by the war's end (Global IDP Project, 2004a). The Ethiopian government estimates that by December 1998, 315,000 Ethiopians were internally displaced, with the two regions that border Eritrea (Tigray and Afar) having the greatest number of internally displaced people (IDPs). The United Nations Country Team Ethiopia estimates that by May 2000 the number of IDPs in Ethiopia had risen to 360,000 (Global IDP Project, 2004b). ${ }^{7}$ By most accounts, households directly affected by the war and those that were internally displaced tended to be located closest to the areas of the clashes.

\section{Data}

\subsection{Demographic and Health Surveys, Eritrea (2002) and Ethiopia (2000 and 2005)}

To measure the war's impact on child health, we use household survey data from both countries, specifically the 2002 Eritrea and 2000 and 2005 Ethiopia Demographic and Health Surveys (DHS). The DHS are nationally representative cross-sectional surveys that have information on demographic topics such as fertility, child mortality, health service utilization, and nutritional status of mothers and young children. The 2002 Eritrea DHS collected detailed information on the date of birth and height of 5,341 children under five born before, during, or after the war with Ethiopia. The 2000 Ethiopia DHS collects similar information for 8,590 children under five, all

\footnotetext{
${ }^{7}$ This level of conflict-induced displacement is typical, as currently 27.1 million individuals worldwide are IDPs due to conflict. For example, during the last decade in Africa, the number of IDPs due to conflict reached 3.5 million in Angola, 633,000 in Burundi, 200,000 in Central African Republic, 180,000 in Chad, 150,000 in Congo-

Brazzaville, 750,000 in Côte d'Ivoire, 3 million in Democratic Republic of Congo, 359,000 in Guinea, 600,000 in Kenya, 450,000 in Liberia, 550,000 in Nigeria, 600,000 in Rwanda, 70,000 in Senegal, 1.3 million in Sierra Leone, 1.5 million in Somalia, 6.1 million in Sudan, 1.7 million in Uganda, and 1 million in Zimbabwe (IDMC, 2010).
} 
of whom were either born before or during the war with Eritrea. To have a control group of children in the war regions of Ethiopia who were not exposed to war, we use the 2005 Ethiopia DHS that has information for 3,875 children under five. We exclude from the baseline analysis the nine percent of these children born before the war ended and use the remaining sample of 3,505 children under 54 months old in 2005. To maintain a consistent age range, we also exclude children who were 54 months or older in the 2000 Ethiopia DHS, yielding a final sample of 11,342 Ethiopian children (7,837 from the 2000 DHS and 3,505 from the 2005 DHS) ${ }^{8}$

\subsection{Health and War Variables}

Child height conditional on age and gender is generally accepted as a good indicator of the longrun nutritional status of children, as height reflects the accumulation of past outcomes, and children with low height for their age are likely to be on a different growth trajectory for the rest of their life (Thomas, Lavy, and Strauss, 1996). We compute Z-scores for each child's heightfor-age, where the Z-score is defined as the difference between the child's height and the mean height of the same-aged international reference population, divided by the standard deviation of the reference population. On average, across households in all regions of Ethiopia, children are 1.77 standard deviations below the average height-for-age of a reference child, and 45.1 percent of children are considered stunted and 22.6 percent are considered severely stunted. ${ }^{9}$ In Eritrea, children are 1.56 standard deviations below the average height-for-age of a reference child, and 39.5 and 17.4 percent of children are respectively considered stunted or severely stunted.

We construct three measures of a child's exposure to the Eritrea-Ethiopia war. The first measure is defined at the region-birth cohort level, (War Region ${ }_{j} *$ Born Before War $_{t}$ ) and (War Region $_{j} *$ Born During War ${ }_{t}$ ), which allows us to exploit variation across two dimensions:

\footnotetext{
${ }^{8}$ Regression results are consistent if all Ethiopian children are included in the subsequent analysis.

${ }^{9}$ Children with height-for-age Z-scores below -2 are considered stunted, while children with height-for-age Z-scores below -3 are considered severely stunted.
} 
spatial (variation across regions in exposure to the war) and temporal (within a given region, the timing of whether a child was born during the war period). These variables are binary and indicate whether a child was born before the war (prior to May 1998) or during the war (between May 1998 and December 2000) in a region that did or did not experience the fighting. As we discussed in Section 2.2, the fighting was centered on the border regions near the three towns of Badme, Tsorona-Zalambessa, and Bure, so in Eritrea, the war regions are defined to include Gash Barka, Debub, and Debubawi Keyih Bahri, while in Ethiopia they are Tigray and Afar. To address potential measurement error that would wrongly misclassify a child as war-exposed because they live in a region that experienced fighting but their village was far from the conflict or a child that was classified as non-war exposed but they lived close to the fighting in a non-war region, the second measure uses GPS information to indicate those survey villages that are geographically close to one of the three conflict sites, (Close to War Site ${ }_{j} *$ Born Before the War $_{t}$ ) and (Close to War Site ${ }_{j}$ * Born During the War ${ }_{t}$ ). These variables are also binary and indicate a child born before or during the war living in a village geographically close to a conflict site. The third measure of a child's war exposure is the duration in months that the child was living in a war region and exposed to the war. The duration measure is set to zero if the child resided in a region that was not affected by the war.

Since war-induced displacement was such an important mechanism through which the conflict impacted child health, we incorporate direct measures of the number of internally displaced people from each region to proxy for the war's intensity in that area. The IDP data come from the United Nations Office for the Coordination of Humanitarian Affairs (UN OCHA) in Eritrea and Ethiopia. All of the IDPs are clustered in the three war regions in Eritrea and the two war regions in Ethiopia mentioned above (Global IDP Project, 2004a, b). 


\subsection{Preliminary Observations}

In Panel A of Table 1, we summarize the height-for-age Z-scores, proportion stunted and severely stunted, gender, and child's age, broken down for each country by whether the child was exposed to conflict. In both countries, war-exposed children (living in a war region and born before or during the war) have lower height-for-age Z-scores and are more likely to be stunted or severely stunted, and the differences are statistically significant. There is no difference in the gender proportion between exposed and non-exposed children.

It is well-known that in developing countries, height-for-age Z-scores have a non-linear relationship with age, with older children having lower Z-scores than younger children, as nutritional and other deficits accumulate with age (Martorell and Habicht, 1986). Panel A of Table 1 shows that, in both countries, war-exposed children are significantly older than nonexposed children. Consequently, the observed negative relationship between conflict and height in Panel A may be affected by this age difference. In Panel B of Table 1, we present preliminary evidence that the conflict-health relationship is not due to this differential age pattern. We compare separately the average height-for-age Z-scores of war-exposed and non-exposed children for children above and below 24 months of age. A similar pattern is observed for younger and older children. Young children who are war-exposed have between 1.21 and 0.41 standard deviations lower height-for-age Z-scores in Eritrea and Ethiopia, respectively, and the differences are statistically significant. Likewise, for older children, there are statistically significant differences of 0.13 and 0.23 standard deviations between war-exposed and nonexposed children. The results provide suggestive evidence that the conflict-health relationship is not solely due to exposed children being slightly older, as results within each age category show 
a large significant different in children’s height-for-age Z-scores. We nonetheless control for age in the subsequent regression analysis by including year of birth fixed effects.

\section{Empirical Identification Strategy}

We illustrate the empirical identification strategy in Figures 2a, 2b, and 2c, in which we estimate kernel-weighted local polynomial regressions of height-for-age Z-scores on date of birth using an Epanechnikov kernel. The dashed lines indicate children living in war regions, while the solid lines indicate children living in non-war regions. Vertical dashed lines show the starting (May 1998) and ending (December 2000) dates of the war. Figure 2a shows results using 2002 Eritrea DHS data; Figure 2b shows results using 2000 Ethiopia DHS data; Figure 2c shows results using 2005 Ethiopia DHS data. Since the 2000 Ethiopia survey was fielded between February and May 2000, the war's end date is not observed in Figure 2b. For all children, the figure shows the expected relationship with older children having lower Z-scores than younger children. In both Eritrea and Ethiopia, children born during the war in the war regions have lower height-for-age Z-scores than children born during the war in the non-war regions. We observe a similar result for the cohorts of children born before the war and therefore who were young children during the war; this is particularly true in Ethiopia. ${ }^{10}$ Finally, Figure 2c shows that in Ethiopia children born after the war ended have similar height-for-age Z-scores in both the war and non-war regions. ${ }^{11}$

The empirical identification strategy relies on a comparison of height-for-age Z-scores of similarly aged children in war and non-war regions. We compare the Z-scores of children born

\footnotetext{
${ }^{10}$ Figure 2b also suggests that children in the war regions in Ethiopia who were more than two years old when the war began (born before May 1996) were less likely to be affected by the war, which is consistent with the theory that disturbances during the early years of life are most harmful to children's growth. In the Eritrea data we do not observe children who were more than two years old at the time the war began.

${ }^{11}$ Figures 3a, 3b, 4a, and 4b show the non-parametric relationship between height-for-age Z-scores and date of birth separately for boys and girls in Eritrea and Ethiopia, respectively. Results are consistent with previous figures.

Height-for-age Z-scores are lower for boys and girls born during the war in the war regions of Eritrea and Ethiopia, and the magnitude of the negative impacts appears comparable for boys and girls. Additionally, both boys and girls who were young at the start of the war in the war regions of Ethiopia have lower height-for-age Z-scores.
} 
before the war ended to the Z-scores of children born after the war ended in the war regions of Eritrea and Ethiopia, and we then compare this difference relative to the same difference in the non-war region in both countries. The implicit assumption is that differences across birth cohorts (born before or after the war ended) in average height-for-age Z-scores would be similar across war and non-war regions in the absence of the conflict. While we use similar identification strategies in Eritrea and Ethiopia, we are able to incorporate additional post-war data that is available only for Ethiopia that allows us to also compare cohorts of similar aged children who are from the same regions but differ in their exposure to the war. Based on the non-parametric regressions, we estimate the following region and birth cohort fixed effects regression:

$$
\begin{aligned}
\mathrm{HAZ}_{i j t} & =\alpha_{j}+\delta_{t}+\beta_{1}\left(\text { WarRegion }_{j} * \text { BornBefore }_{\text {War }_{t}}\right) \\
& +\beta_{2}\left(\text { WarRegion }_{j} * \text { BornDuring } \text { War }_{t}\right)+\varepsilon_{i j t}
\end{aligned}
$$

where $H A Z_{i j t}$ is the height-for-age Z-score for child $i$ in region $j$ who was born in period $t, \alpha_{j}$ are region fixed effects, $\delta_{t}$ are year of birth cohort fixed effects, War Region ${ }_{j} *$ Born Before War $_{t}$ is a binary variable indicating whether a child was born before the war started in a war-affected region, War Region ${ }_{j}$ * Born During War $_{t}$ is a binary variable indicating whether a child was born during the war in a war-affected region, and $\varepsilon_{i j t}$ is a random, idiosyncratic error term. The coefficient $\beta_{1}$ measures the war's impact on children's height-for-age Z-scores for children born before the war in war-affected regions, while the coefficient $\beta_{2}$ measures the impact of the war on children's height-for-age Z-scores for children born during the war in war-affected regions.

In defining geographic war exposure based on living in one of the three regions in Eritrea or two regions in Ethiopia where fighting took place, we are potentially including villages far from the war sites that may not have been affected by conflict. This is potentially problematic as some regions extend many kilometers from the war sites (see Afar in Ethiopia and Debubawi Keyih Bahri in Eritrea). Likewise, we might be excluding households close to war sites that may 
have been affected by conflict, but were living in a non-war region (see Semenawi Keyih Bahri in Eritrea). To more accurately measure a child's war exposure, our empirical strategy takes advantage of information on the distance of each survey village to the three main conflict sites. We use the distance to the nearest war site (even if it crosses region boundaries) to classify intensity of war exposure. Since the mean distance to the closest conflict site within the war regions is 75 kilometers in Eritrea and 125 kilometers in Ethiopia, we use those distances to define binary variables indicating households living close to any of the war sites. ${ }^{12}$ We then estimate the following modified Equation 1 with Close to War Site replacing War Region $_{j}$ :

$$
\begin{aligned}
& \text { HAZ }_{i j t}=\alpha_{j}+\delta_{t}+\beta_{3}\left(\text { CloseToWar Site }_{j} * \text { BornBefore } \text { War }_{t}\right) \\
&+\beta_{4}(\text { CloseTo WarSite } \\
& j
\end{aligned}
$$

Equations 1 and 2 contain binary variables indicating whether a child was born before or during the war in war-affected areas. We also use a continuous measure of war exposure in estimating the following region and birth cohort fixed effects regression:

$$
H A Z_{i j t}=\alpha_{j}+\delta_{t}+\beta_{5}\left(\text { Monthsof WarExposur } e_{j t}\right)+\varepsilon_{i j t}
$$

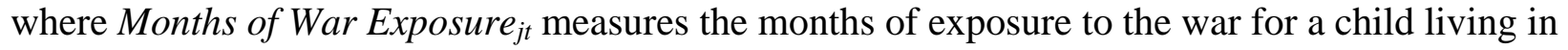
a war-affected region and equals zero for a child living in a non-war region. The coefficient $\beta_{5}$ measures the impact of an additional month of war exposure on children's height-for-age Zscores.

The empirical strategy in Equations 1, 2, and 3 assumes that, in the absence of war, the difference between the height-for-age Z-scores of children born before and after the war ended in war-affected regions would have been the same as the difference for children living in non-war regions. To address the potential for differential time trends in height-for-age Z-scores across regions, we add region-specific time trends to each of the previous equations as follows:

\footnotetext{
${ }^{12}$ In Section 5.3, we discuss the robustness of using alternative distance cut-offs as well as a continuous distance measure to examine geographic proximity to the fighting.
} 


$$
\begin{aligned}
\operatorname{HAZ}_{i j t} & =\alpha_{j}+\delta_{t}+\beta_{1}\left(\text { WarRegion }_{j} *{\text { BornBefore } \left.\text { War }_{t}\right)}\right) \\
& +\beta_{2}\left(\text { WarRegion }_{j} * \text { BornDuring } \text { War }_{t}\right)+\text { Region Trend }_{j t}+\varepsilon_{i j t}
\end{aligned}
$$

where the variables are as previously defined and Region Trend $_{j t}$ is a region-specific time trend that isolates the variation in children's outcomes that diverge from region time trends. The inclusion of this time trend buttresses the argument that changes in average height-for-age Zscores in these regions would have been similar in the absence of the war.

Equation 4 assumes that, apart from the war, there are no other events that might have coincided with the war and independently affected children's health. Since this assumption may be violated, we might incorrectly attribute a decline in children's health to the war. To address this possibility and to highlight that the health differences across regions and birth cohorts are due to the war, we use the number of internally displaced people from every region as a proxy for the war's intensity in that region. This allows us to better identify the war's impact, as we compare regions with many IDPs to regions with few IDPs. The change in the health status of children born after the war ended in high war intensity regions relative to low war intensity regions serves as a control for what the change in the health status of children born before the war ended would have been if the war did not occur. We estimate a modified Equation 4 where we replace War Region ${ }_{j}$ with War Intensity, which indicates the number of IDPs from region $j$.

Since the war intensity variable (number of IDPs from a region) may be measured with error or may be endogenous due to correlations with village or household level characteristics that influence child health, we also use an instrumental variables strategy. We use the GPS distance information on village location, specifically the variable Close to War Site , to

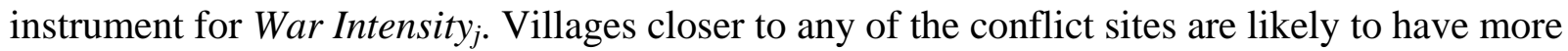
displaced people due to fighting. The strategy assumes that the distance to any of the conflict sites has no impact on health status other than through the war between the two countries. 


\section{Empirical Results}

\subsection{Baseline Difference-in-Differences Estimation}

Table 2 presents baseline regressions for the difference-in-differences estimation of the war's impact on height-for-age Z-scores as outlined in Equations 1 to 3. All regressions include region and year of birth cohort fixed effects and control for child gender. ${ }^{13}$ The first three columns show results for Eritrea; the last three columns show results for Ethiopia. Results in Columns 1 and 4 show a negative impact of the conflict on children born during the war in the war regions of Eritrea and Ethiopia. Children born during the war in a war region have Z-scores 0.24 and 0.59 standard deviations lower than non-war exposed children in Eritrea and Ethiopia, respectively. This reduction is statistically significant in both countries. The impact of the war represents, respectively in Eritrea and Ethiopia, a decline of 13 and 44 percent compared to the average height-for-age Z-score of children born during the war in a non-war region. Results in Column 1 show no significant conflict impact on children born before the war started in the Eritrea war regions. However, children born before the war in Ethiopia have Z-scores 0.48 standard deviations lower than children born after the war. This impact is statistically significant and represents a decline of 22 percent compared to the average height-for-age Z-score of children born before the war in the non-war regions of Ethiopia. In Columns 2 and 5, we estimate the regression described in Equation 2 using the discrete measure indicating villages close to any of the three conflict sites, which can be considered a more accurate measure of a child's war exposure. Results are consistent with those in Columns 1 and 4, indicating that geographic misclassification errors of war exposure are not severe in this context when delineating exposure by war region. In Columns 3 and 6 , we use the number of months of war exposure as a measure

\footnotetext{
${ }^{13}$ Correlation among the error terms of children living in the same local environment and experiencing similar health shocks might bias the OLS standard errors downward, so in all regressions we cluster the standard errors by enumeration area, which corresponds to local clusters of villages (Moulton, 1986).
} 
of a child's conflict exposure, as in Equation 3. The duration measure has a significant negative impact on children's Z-scores in Ethiopia; an additional month of war exposure reduces a child's height-for-age by 0.023 standard deviations. However, in these initial regressions, the duration of war exposure has no statistically significant impact on children’s Z-scores in Eritrea.

Table 3 presents our preferred baseline specification as described in Equation 4 and includes region-specific time trends to control for the possibility of differential trends across regions. In Ethiopia, results in Table 3 are similar to those in Table 2. Children born during the war in a war region or in a village close to a war site experience 0.53 or 0.45 standard deviations lower Z-scores, respectively. Effects similar in magnitude (0.52 and 0.50 standard deviations) are found for children born before the war and who experience the conflict as a young child in either the war region or close to a war site. In Eritrea, point estimates are relatively higher compared to Table 2 when the impact of the war is measured using discrete variables as in Column 1 (0.39 standard deviations) and Column 2 (0.37 standard deviations), and considerably larger when using the continuous months of war exposure in Column 3 (0.04 standard deviations lower Zscores for each additional month of war exposure). These results with time trends suggest the war in Eritrea affected regions where children's health status was actually improving.

To test whether children born during the war experience a differential impact of war exposure compared to children born before the war started, in Table 3 we present the p-values for the test of the null hypothesis that $\beta_{1}=\beta_{2}$ in Equation 1 (using war region), as well as its counterpart $\beta_{3}=\beta_{4}$ in Equation 2 (using close to war site). Focusing on our preferred specification including region-specific time trends, in Ethiopia, we cannot reject the null hypothesis of equality between the two coefficients. In Eritrea, the negative impact is larger for children born during the war, although the difference is only statistically significant at the ten 
percent level for the close to war site variable (Column 2). Overall, this suggests that the impact of the war on children born during the war in regions affected by conflict is similar to the war's impact on children born before the war started in the war regions.

Table 4 (boys only) and Table 5 (girls only) explore the heterogeneity of the war impact by gender. Unlike the literature on shocks that generally finds a large negative bias against girls, in our study when the shock is a war, both genders are negatively impacted by exposure. In both countries, boys and girls born during the conflict in the war regions or close to a war site have significantly lower height-for-age Z-scores and additional months of war exposure also lower Zscores. The magnitude of the impact is slightly larger for boys, although in a fully interacted model, we cannot reject the equality of coefficients for boys and girls. ${ }^{14}$

\subsection{War Intensity Measures and Instrumental Variables}

Given the war represented such a large shock and occurred mainly in the border areas between the two countries, the identification strategy used so far is likely to correctly identify the impact of the Eritrea-Ethiopia war on children's health status. However, we recognize that during the same time period other events may have occurred that might be correlated with both the war's occurrence and with changes in children's health status. If this were the case, we might be incorrectly attributing the observed decline in health status to the war. Table 6 examines this potential source of bias. In Panel A, we estimate a difference-in-differences regression using measures of war intensity (the number of IDPs from every region divided by 10,000) interacted with indicators of whether the child was born during or before the war. Negative coefficients for these interaction terms would suggest that previous results are indeed due to the war rather than

\footnotetext{
${ }^{14}$ We also estimated regressions in which the sample of children in each country was divided into poor and nonpoor households based the education of the household head. Results (not shown) suggest that the negative impact of the war is similar among poor and non-poor children.
} 
to other events. ${ }^{15}$ Column 1 shows results for Eritrea; Column 2 shows the Ethiopia results. All specifications include region and age fixed effects, region-specific time trends, and child gender.

In Eritrea, results indicate that children born during the war in higher war intensity areas have lower height-for-age Z-scores and results are statistically significant. An increase in the number of IDPs in a region by 10,000 lowers the Z-scores for children born during the war by 0.023 standard deviations. Children born before the war experience a similar negative impact (0.022 standard deviations), although the coefficient is not significant at standard levels. Results are consistent in Ethiopia, with children born during or before the war in higher war intensity regions having lower height-for-age and the coefficients are statistically significant.

To address the possibility that the war intensity variables could be measured with error or might be correlated with village or household level characteristics that influence child health, we use the GPS distance information on village location, specifically the variable Close to War Sitej,

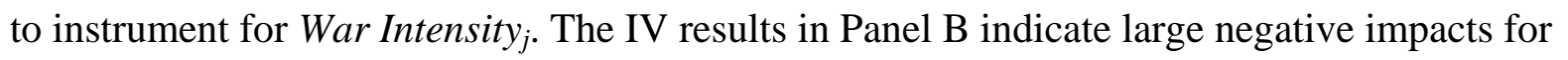
children born during or before the war in higher intensity war regions in both Eritrea and Ethiopia. ${ }^{16}$ In Eritrea, a child born during or before the war in a region experiencing the mean war intensity (average number of IDPs across all regions in Eritrea is 58,030) has 0.39 or 0.42 standard deviations lower height-for-age Z-scores, respectively. This negative impact represents declines of 21 and 24 percent relative to the average height-for-age Z-scores of children born during or before the war in the non-war regions, respectively. The true impact for a war-exposed child is even larger, as the mean war intensity in the above calculation is averaged across all

\footnotetext{
${ }^{15}$ Results (not shown) are also consistent when we estimate the regressions using the number of IDPs per capita as the war intensity measure.

${ }^{16}$ The F-statistics for the excluded instruments are well above the threshold that would indicate a potential weak instrument bias. Based on the Kleibergen-Paap test for weak instruments in the presence of multiple endogenous variables and non-i.i.d. error terms, we do not find any evidence for Eritrea (test statistic of 24.78) or Ethiopia (test statistic of 42.22) that our results suffer from this bias (Kleibergen-Paap 2006; Baum, Schaffer, and Stillman 2007).
} 
regions, some of which had no IDPs. Using the average number of IDPs only from the war regions of Eritrea $(111,690)$ shows negative impacts of 0.76 and 0.82 standard deviations, representing 40 and 46 percent declines compared to the average Z-scores of children born during or before the war in the non-war regions, respectively. Negative and statistically significant results are also found for war-exposed children in Ethiopia, although the magnitude of the impact is greatly reduced. A child born during or before the war in a region experiencing the mean war intensity (average number of IDPs across all regions of Ethiopia is 27,330) has 0.05 or 0.07 standard deviations lower height-for-age Z-scores, representing declines of 4 and 3 percent, respectively, compared to the average Z-scores of children born during or before the war in the non-war regions of Ethiopia. As many regions in Ethiopia were not part of the war, using the average number of IDPs only from the war regions of Ethiopia $(163,500)$ shows negative impacts of 0.31 or 0.41 standard deviations, representing 23 and 19 percent declines compared to the average Z-scores of children born during or before the war in non-war regions, respectively.

\subsection{Robustness Checks}

To test the robustness of our findings, we evaluate several placebo war-impact specifications and also explore how issues of displacement and migration, misspecification of our geographic exposure variables, age misreporting, and selective mortality might influence the results. We estimate several placebo-type regressions for Eritrea and Ethiopia in which non-war regions were labeled as if they were war regions and then compared to the other non-war regions. Results show no significant impact on height-for-age Z-scores in these non-war regions. Moreover, in Ethiopia we have pre-war regional poverty data and confirm results are similar when the non-war regions are limited to those with similar pre-war poverty levels as the war regions. These placebo and robustness checks provide additional evidence supporting the paper’s main results. 
Due to the war, thousands of people were internally displaced in both countries.

Migration of this nature, particularly if people moved across regions, may bias our estimates because we would incorrectly determine a child's war exposure based on the child's current region of residence, which might be incorrect if the child resided in a different region during the war. In Table 7, we restrict the child sample by incorporating two alternative residency definitions to gauge the potential misspecification bias. Columns 1 and 3 restrict the sample to now only include children who were born in their current residence. Columns 2 and 4 further restrict the sample to only include children born in their current residence and whose families lived in their current residence during the war. ${ }^{17}$ Panel A estimates the difference-in-differences specification; Panel B incorporates the war intensity measure; Panel C instruments for war intensity using the close to war site variable as an instrument. The size of the impact and the level of statistical significance are consistent with the non-restricted sample, providing evidence of minimal bias introduced by incorrectly misclassifying residency. ${ }^{18}$

Given our focus on accurately measuring geographic exposure to the war, we estimate robustness regressions (results not shown) that use alternative distance cut-offs for the variable indicating villages close to any of the three conflict sites. The current variable is based on the mean distance to the closest conflict site within the war regions (75 kilometers in Eritrea and 125 kilometers in Ethiopia). Results are quantitatively similar using 100 or 125 kilometers as the distance cut-off for Eritrea or 150 or 250 kilometers in Ethiopia. Finally, we estimate regressions

\footnotetext{
${ }^{17}$ Instead of excluding children not born in the current place of residence, a more accurate approach would consider a child's region of residence during the war, but in the data only duration at the current residence is available.

${ }^{18}$ It is also possible that households experiencing negative shocks sent out children to live with other relatives (see Akresh (2009) for evidence on the link between negative income shocks and child fostering). Although we do not have any information in the survey about this, we are unable to tell which direction, if any, this might bias the results depending on whether the most healthy or the least healthy child was fostered, but most of the child fostering literature finds the rate of fostering for children under age five to be extremely low.
} 
using a continuous measure of distance. Results are consistent; children born during the war and living closer to a conflict site have significantly lower height-for-age Z-scores.

Lastly, our analysis likely underestimates the shock's true health impact for two reasons. First, a child's age could be mismeasured, and if this occurred, it would likely mean our estimates are lower bounds of the true impact, as parents would probably underreport the age of short children making their malnutrition seem less severe than it is. The chance of this is reduced since the household roster collects the exact birth date of all the household's children under five and misreporting on one child would be more difficult as it would influence the birth dates of the household's other children. Second, child mortality might be higher in war-exposed households. Unfortunately, we do not have health data on children who died prior to the survey, but these deceased children were likely the weakest and smallest, which means we are underestimating the total war impact. Therefore, the reported effects should be interpreted as the war's impact on child health, conditional on the child surviving to be recorded in the survey.

\subsection{Comparison of War Impact in Eritrea and Ethiopia}

To the best of our knowledge, this is the first paper to use data from both countries involved in an international war to measure the impact of a conflict on children's health. Given this unique characteristic of the paper, in this section we attempt to compare the war's impact in Eritrea with its impact in Ethiopia. In Table 8, we analyze both countries simultaneously, using the previous specifications from Table 3 focusing on war regions and from Table 6 incorporating war intensity and an instrumental variables estimation. To capture the differential impact of the war in Ethiopia compared to Eritrea, in all specifications we include an interaction term of the main variables with an indicator variable for living in Ethiopia. All specifications include region and year of birth fixed effects, region-specific time trends, and control for child gender. 
Results in Column 1 show negative impacts of the conflict on children born during or before the war in Eritrea's war-affected regions, with these children having, respectively, 0.43 or 0.37 standard deviations lower Z-scores than non-war exposed children, and the differences are statistically significant. Even though the point estimate of the war's negative impact in Ethiopia is larger, the difference with Eritrea is not statistically significant. Results in Columns 2 and 3 use the number of IDPs as a measure of war intensity as in Table 6. Column 2 presents OLS results; Column 3 instruments for war intensity using the variable indicating villages close to a conflict site. ${ }^{19}$ The magnitude of the negative impacts is consistent with the earlier results. If we focus on the preferred IV specification and use the average number of IDPs in the war regions of Eritrea and Ethiopia, we find that a child born during or before the war in Eritrea in a region with the mean war intensity has, respectively, 0.77 or 0.89 standard deviations lower height-for-age Z-scores. The war impact in Ethiopia compared to Eritrea is much lower for children born during or before the war, although only the difference for children born during the war is statistically significant. A child born during or before the war in Ethiopia in a region with the mean war intensity has, respectively, 0.31 or 0.41 standard deviations lower height-for-age Z-scores. The similarity of the magnitude of war impacts across Eritrea and Ethiopia and compared to those reported in the Burundi civil war (Bundervoet, Verwimp, Akresh, 2009) provides some confirmation of the external validity of these results.

\subsection{Discussion of the War Impact Mechanisms}

Understanding the specific mechanisms by which conflict impacts child health is critical for developing adequate policy responses to protect children from the negative effects of war. In order to fully answer this question, we would require detailed household level data on crop

\footnotetext{
${ }^{19}$ For the IV regression in Column 3, the F-statistics for the excluded instruments as well as the Kleibergen-Paap test do not indicate any potential weak instrument bias.
} 
production and assets, information on the extent and duration of displacement (including changes in nutrition and exposure to disease and unclean water), and detailed conflict event data at the household level to accurately measure war exposure. Despite the lack of such data, our results provide some suggestive indication of the likely mechanisms by which war impacts child health.

A first possible mechanism is that the war hindered the provision of food aid distributed by the international community. However, there is evidence that donors did not restrict food aid provision, at least in Ethiopia, and in fact, some countries began to help these nations for the first time. Several reports also indicate the war did not interfere with food aid distribution. While we do not have data on the amount of relief aid disaggregated by region, if such aid were targeted disproportionately to war-affected regions, then this paper's results would underestimate the true impact of the conflict. A second possible mechanism, one that is more common in civil wars in Africa, is the theft of assets, including livestock. Since it takes time to reverse such a loss, poverty generated by asset theft would affect all children in the household, regardless of if they are born during or after the war. Our results suggest this mechanism might not have been salient, as only children born before the war ended are impacted. In addition, there is some anecdotal evidence of stray Eritrean cattle returned by the Ethiopian army and vice versa.

Our results support displacement and deportations as the main mechanism through which the war impacted children's health status. Thousands of Eritreans living in Ethiopia and Ethiopians living in Eritrea were violently deported back to their respective countries and many families were internally displaced on both sides of the border due to the war. Because of this displacement, many households were worse off since they lost their harvests and assets, were forced to disrupt their businesses, and had limited access to medicines and clean water. A child exposed to displacement would be worse-off compared to a non-exposed child, and the impact 
should be larger the longer the child is exposed to these events. Our war intensity results suggest that displacement is an important impact mechanism; the instrumental variable estimates show significant effects for those born before and during the war in both countries.

\section{Conclusion}

This is the first paper able to measure the welfare impacts on both sides involved in a conflict, thus providing a more thorough understanding of how wars impact well-being. We use nationally representative Demographic Health Survey data to assess the short- and medium-term impacts of the 1998-2000 Eritrea-Ethiopia war on the health status of young children in both countries. The war between Eritrea and Ethiopia led to thousands of people being displaced from their homes, as is the case for many conflicts in sub-Saharan Africa. Our identification strategy exploits exogenous variation in the conflict's geographic extent and timing and the subsequent exposure of different children's birth cohorts to the fighting. Using alternative measures of war exposure and conflict intensity, we find that war has a large negative impact on height-for-age Z-scores of children in both the winning and losing nations. Results from our instrumented specification indicate that children born during or before the war and living in a region with the mean number of internally displaced people have significantly lower height-for-age Z-scores as a result of war exposure. The magnitude of the negative impacts ranges from 0.77 to 0.89 standard deviations in Eritrea and 0.31 to 0.41 standard deviations in Ethiopia, sizable effects compared to the average Z-scores of children in non-war regions of both countries. War impacts are similar for boys and girls, and our results are robust to consideration of various issues such as migration out of affected areas, age misreporting, and higher mortality among war-affected households.

A critical reason for studying the impact of war on children's height is that this health indicator is known to influence future health, education, and economic outcomes. Based on other 
estimates of the links between height-for-age Z-scores and schooling attainment and wages, we can speculate on the long-term consequences that follow from our estimates of the negative health impact of the Eritrea-Ethiopia war. Specifically, we base our calculation on the estimate that a one standard deviation reduction in height correlates with 0.678 fewer grades completed in Zimbabwe (Alderman, Hoddinott, and Kinsey, 2006) and that the return to an extra year of education in Ethiopia is 15 percent (Krishnan, Selassie, and Dercon, 1998). Using these estimated links and the magnitude of the impacts discussed above, we find that for children born during the war in Eritrea and Ethiopia, wages in adulthood will be, respectively, 7.8 and 3.2 percent lower. For children born before the war, the negative health impacts will translate into a 9.1 and 4.2 percent reduction in expected adult wages in Eritrea and Ethiopia, respectively.

The results in this paper contribute to a growing literature that estimates the welfare impacts of wars. The external validity of results in this literature is often contested because each war is different in its scale and scope. However, the case of the Eritrea-Ethiopia war and our estimation of similar negative impacts on children's health in both countries suggest that wars often result in adverse effects on young children. The findings in this paper also help improve our understanding of a broader issue, which are the long-term growth and development consequences of wars. As undernourishment during early years has been linked to worse economic outcomes in adulthood, the long-term legacy of war, for both the winning and losing nations, is a problem that may need to be addressed with various educational and economic interventions in the future. 


\section{References}

Akbulut-Yuksel, Mevlude. 2009. "Children of War: The Long-Run Effects of Large-Scale Physical Destruction and Warfare on Children.” IZA Discussion Paper 4407.

Akresh, Richard. 2009. "Flexibility of Household Structure: Child Fostering Decisions in Burkina Faso.” Journal of Human Resources, 44(4): 976-997.

Akresh, Richard, and Damien de Walque. 2008. "Armed Conflict and Schooling: Evidence from the 1994 Rwandan Genocide.” IZA Discussion Paper 3516.

Alderman, Harold, John Hoddinott, and Bill Kinsey. 2006. "Long Term Consequences of Early Childhood Malnutrition.” Oxford Economic Papers, 58(3): 450-474.

Angrist, Joshua. 1990. "Lifetime Earnings and the Vietnam Era Draft Lottery: Evidence from Social Security Administrative Records.” American Economic Review, 80(3): 313-336.

Barker, David J.P. 1998. Mothers, Babies, and Health in Later Life. Edinburgh, United Kingdom: Churchill Livingstone.

Baum, Christopher, Mark Schaffer, and Steven Stillman. 2007. "Enhanced Routines for Instrumental Variables/GMM Estimation and Testing." Boston College Department of Economics, Working Paper No 667.

Bellows, John, and Miguel, Edward. 2009. "War and Local Collective Action in Sierra Leone." Journal of Public Economics, 93(11-12): 1144-1157.

Blattman, Christopher, and Jeannie Annan. 2010. "The Consequences of Child Soldiering." Review of Economics and Statistics, 92(4): 882-898.

Brakman, Steven, Harry Garretsen, and Marc Schramm. 2004. "The Strategic Bombing of German Cities During World War II and Its Impact on City Growth.” Journal of Economic Geography, 4(2): 201-218

Bundervoet, Tom, Philip Verwimp, and Richard Akresh. 2009. "Health and Civil War in Rural Burundi.” Journal of Human Resources, 44(2): 536-563.

Collier, Paul, and Anke Hoeffler. 1998. "On the Economic Causes of Civil War.” Oxford Economic Papers, 50(4): 563-573.

Davis, Donald, and David Weinstein. 2002. "Bones, Bombs, and Break Points: The Geography of Economic Activity.” The American Economic Review, 92(5): 1269-1289.

Dercon, Stephan, and Pramilla Krishnan. 2000. "In Sickness and in Health: Risk Sharing Within Households in Rural Ethiopia.” Journal of Political Economy, 108(4): 688-727. 
Do, Quy-Toan, and Lakshmi Iyer. 2010. “Geography, Poverty and Conflict in Nepal.” Journal of Peace Research, 47(6): 735-748.

Eritrea Ethiopia Claims Commission. 2005. "Partial Award Jus Ad Bellum Ethiopia’s Claims 1-8 between The Federal Democratic Republic of Ethiopia and The State of Eritrea.” The Hague, December 19, 2005.

Gleditsch, Nils, Peter Wallensteen, Mikael Eriksson, Margareta Sollenberg, and Havard Strand. 2002. “Armed Conflict 1946-2001: A New Dataset.” Journal of Peace Research, 39(5): 615-637.

Global IDP Project. 2004a. "Profile of Internal Displacement: Eritrea, Compilation of the Information Available in the Global IDP Database of the Norwegian Refugee Council.”

Global IDP Project. 2004b. "Profile of Internal Displacement: Ethiopia, Compilation of the Information Available in the Global IDP Database of the Norwegian Refugee Council.”

GlobalSecurity.org. 2000. http://www.globalsecurity.org/military/world/war/eritrea.htm (accessed December 1, 2010).

Guidolin, Massimo, and Eliana La Ferrara. 2007. "Diamonds are Forever, Wars Are Not: Is Conflict Bad for Private Firms?” American Economic Review, 97(5): 1978-1993.

Humphreys, Macartan, and Jeremy Weinstein. 2007. "Demobilization and Reintegration." Journal of Conflict Resolution, 51(4): 531-567.

Human Rights Watch. 2003. "The Horn of Africa War: Mass Expulsions and the Nationality Issue.” Human Rights Watch, 15(3A).

Ichino, Andrea, and Rudolf Winter-Ebmer. 2004. "The Long-Run Education Cost of World War II.” Journal of Labor Economics, 22(1): 57-86.

Imbens, Guido, and Wilbert van der Klaauw. 1995. "Evaluating the Cost of Conscription in The Netherlands.” Journal of Business and Economic Statistics 13(2): 207-215.

Internal Displacement Monitoring Center (IDMC). 2010. "Internal Displacement: Global Overview of Trends and Developments in 2009."

Kleibergen, Frank, and Richard Paap. 2006. "Generalized Reduced Rank Tests Using the Singular Value Decomposition.” Journal of Econometrics, 127(1): 97-126.

Krishnan, Pramila, Tesfaye Selassie, and Stefan Dercon. 1998. "The Urban Labor Market During Structural Adjustment: Ethiopia 1990-1997.” Report No. WPS 98-9. Center for the Study of African Economies, Oxford University. 
Maccini, Sharon, and Dean Yang. 2009. "Under the Weather: Health, Schooling, and Socioeconomic Consequences of Early-Life Rainfall.” American Economic Review, 99(3): 1006-1026.

Maluccio, John, John Hoddinott, Jere Behrman, Reynaldo Martorell, Agnes Quisumbing, and Aryeh Stein. 2009. "The Impact of Improving Nutrition During Early Childhood on Education among Guatemalan Adults.” Economic Journal, 119(537): 734-763.

Martorell, Reynaldo, and Jean-Pierre Habicht. 1986. "Growth in Early Childhood in Developing Countries.” In Human Growth: A Comprehensive Treatise. F. Falkner and J. Tanner, Editors. Plenum Press. New York.

Miguel, Edward, Shanker Satyanath, and Ernest Sergenti. 2004. "Economic Shocks and Civil Conflict: An Instrumental Variables Approach.” Journal of Political Economy, 114(4): 725-753.

Miguel, Edward, and Gerard Roland. 2011. "The Long Run Impact of Bombing Vietnam.” Journal of Development Economics, forthcoming.

Moulton, Brent. 1986. "Random Group Effects and the Precision of Regression Estimates.” Journal of Econometrics, 32(3): 385-397.

Rose, Elaina. 1999. “Consumption Smoothing and Excess Female Mortality in Rural India.” Review of Economics and Statistics, 81(1): 41-49.

Shemyakina, Olga. 2011. "The Effect of Armed Conflict on Accumulation of Schooling: Results from Tajikistan.” Journal of Development Economics, forthcoming

Stein, Zena, Mervyn Susser, Gerhart Saenger, and Francis Marolla. 1975. Famine and Human Development: The Dutch Hunger Winter of 1944-1945. New York: Oxford Press.

Strauss, John, and Duncan Thomas. 2008. “Health Over the Life Course.” In Handbook of Development Economics, vol. 4, ed. Paul Schultz and John Strauss, 3375-3474. Amsterdam: North-Holland.

Swee, Eik. 2009. “On War and Schooling Attainment: The Case of Bosnia and Herzegovina.” Households in Conflict Network Working Paper 57.

Thomas, Duncan, Victor Lavy, and John Strauss. 1996. "Public Policy and Anthropometric Outcomes in the Cote D’Ivoire.” Journal of Public Economics, 61(2): 155-92.

United States Central Intelligence Agency. 2010. “CIA World Factbook” Downloaded from www.cia.gov on November 27, 2010. 
Figure 1: Eritrea and Ethiopia Regional Map Indicating Conflict Sites

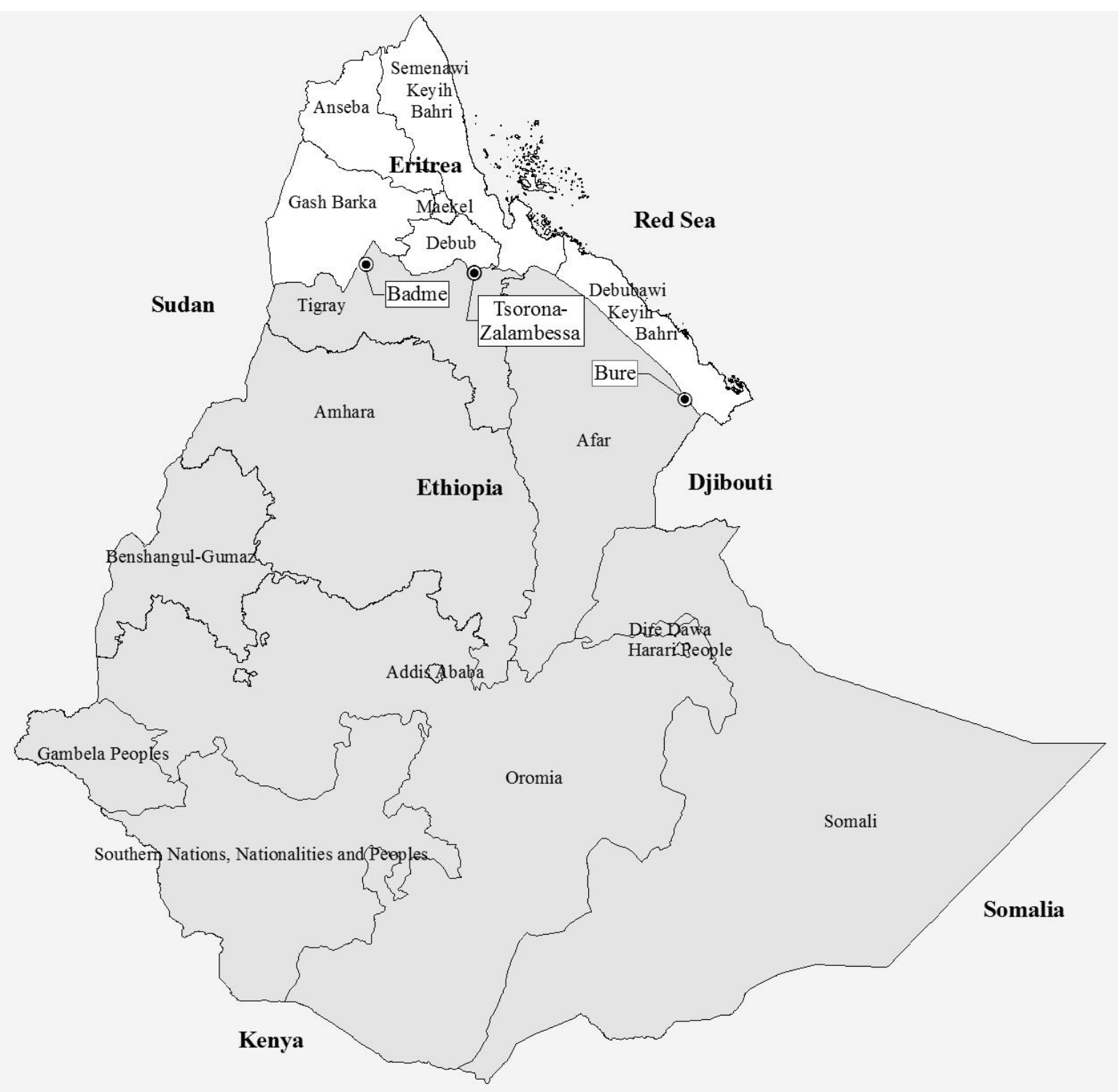

Notes: The main fighting between Eritrea and Ethiopia occurred around the areas of Badme, Tsorona-Zalambessa, and Bure, which are noted on the map. Map source: Constructed by Rafael Garduño-Rivera in ArcGIS. 
Figure 2a: Height-for-age Z-scores by Month and Year of Birth and War Exposure in Eritrea in 2002 (War and Post-War Period)

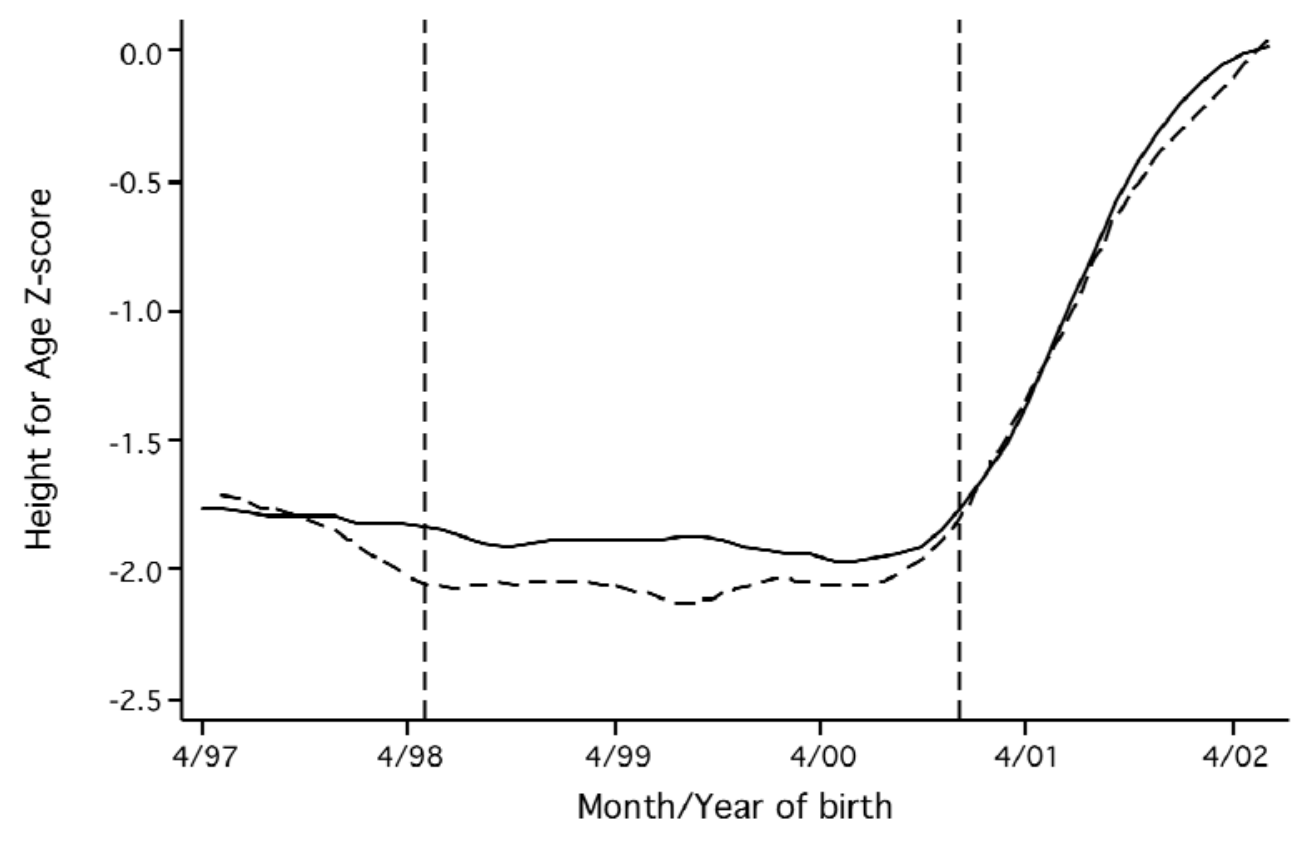

---- War Regions $\quad$ Non-war Regions

Notes: Kernel-weighted local polynomial regression (using Epanechnikov kernel) of height-for-age Z-score on month and year of birth. Dashed line indicates children living in war regions. Solid line indicates children living in non-war regions. Vertical dashed lines show the starting (May 1998) and the ending dates (December 2000) of the war. Birth cohorts were either born before the war started, during the war, or after the war ended. Data source: 2002 Eritrea Demographic and Health Survey. 
Figure 2b: Height-for-age Z-scores by Month and Year of Birth and by War Exposure in Ethiopia in 2000 (War Period)

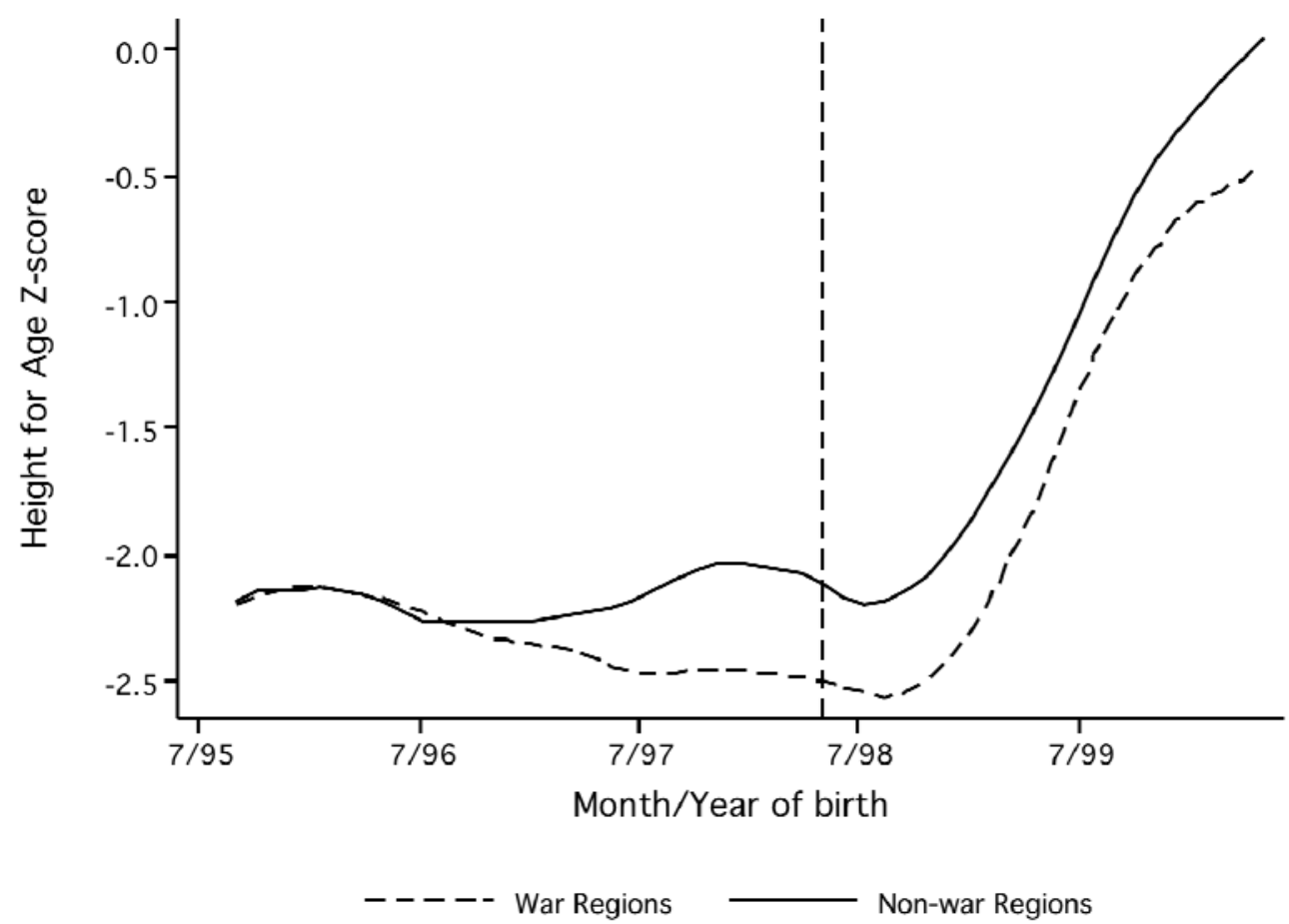

Notes: Kernel-weighted local polynomial regression (using Epanechnikov kernel) of height-for-age Z-score on month and year of birth. Dashed line indicates children living in war regions. Solid line indicates children living in non-war regions. Vertical dashed line shows the starting date (May 1998) of the war. All birth cohorts were either born before the war started or during the war. Data source: 2000 Ethiopia Demographic and Health Survey. 
Figure 2c: Height-for-age Z-scores by Month and Year of Birth and by War Exposure in Ethiopia in 2005 (Post-War Period)

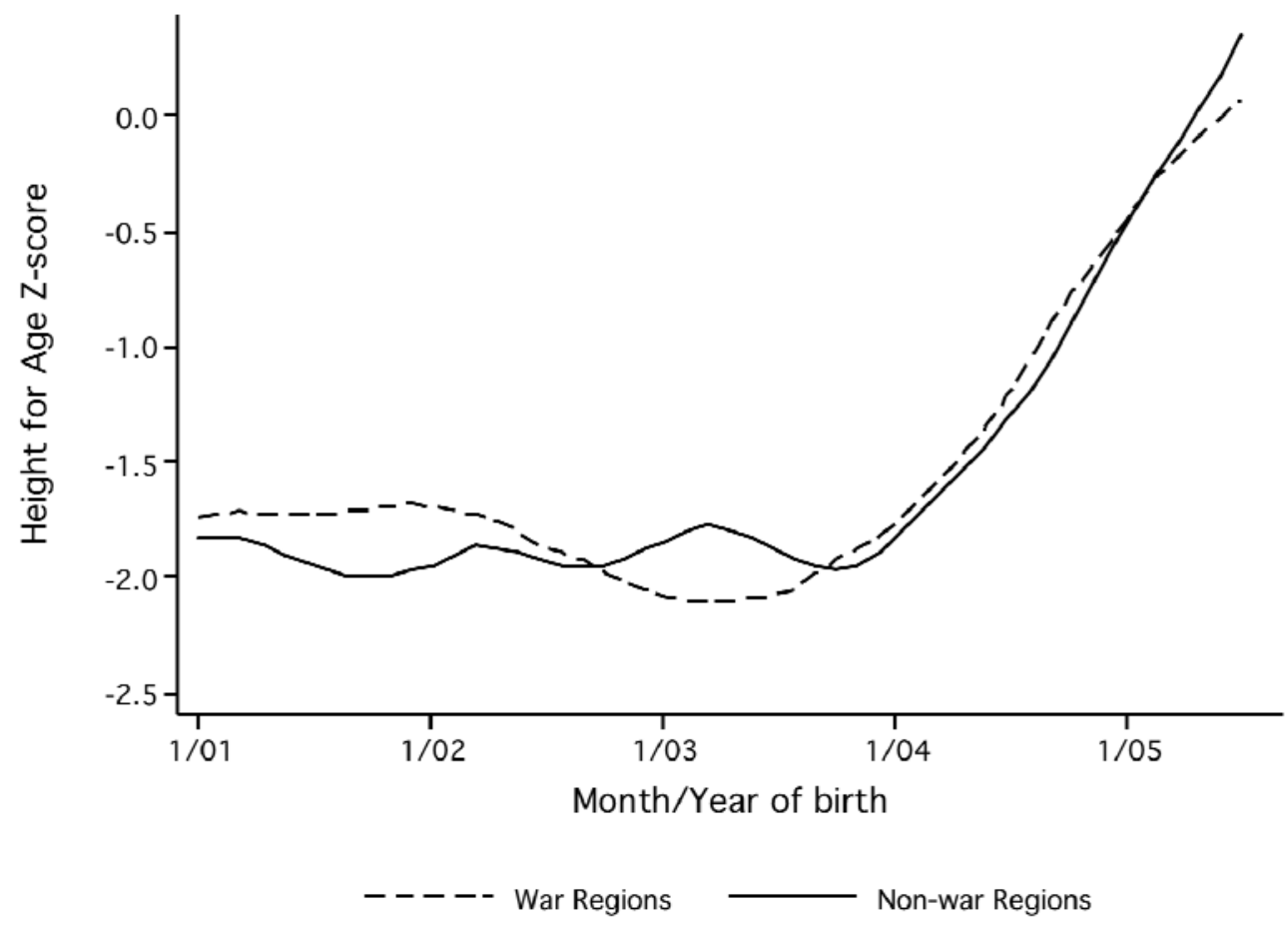

Notes: Kernel-weighted local polynomial regression (using Epanechnikov kernel) of height-for-age Z-score on month and year of birth. Dashed line indicates children living in war regions. Solid line indicates children living in non-war regions. All birth cohorts were born after the war ended. Data source: 2005 Ethiopia Demographic and Health Survey. 
Figure 3a: Height-for-age Z-scores by Month and Year of Birth and War Exposure in Eritrea in 2002, Boys Only

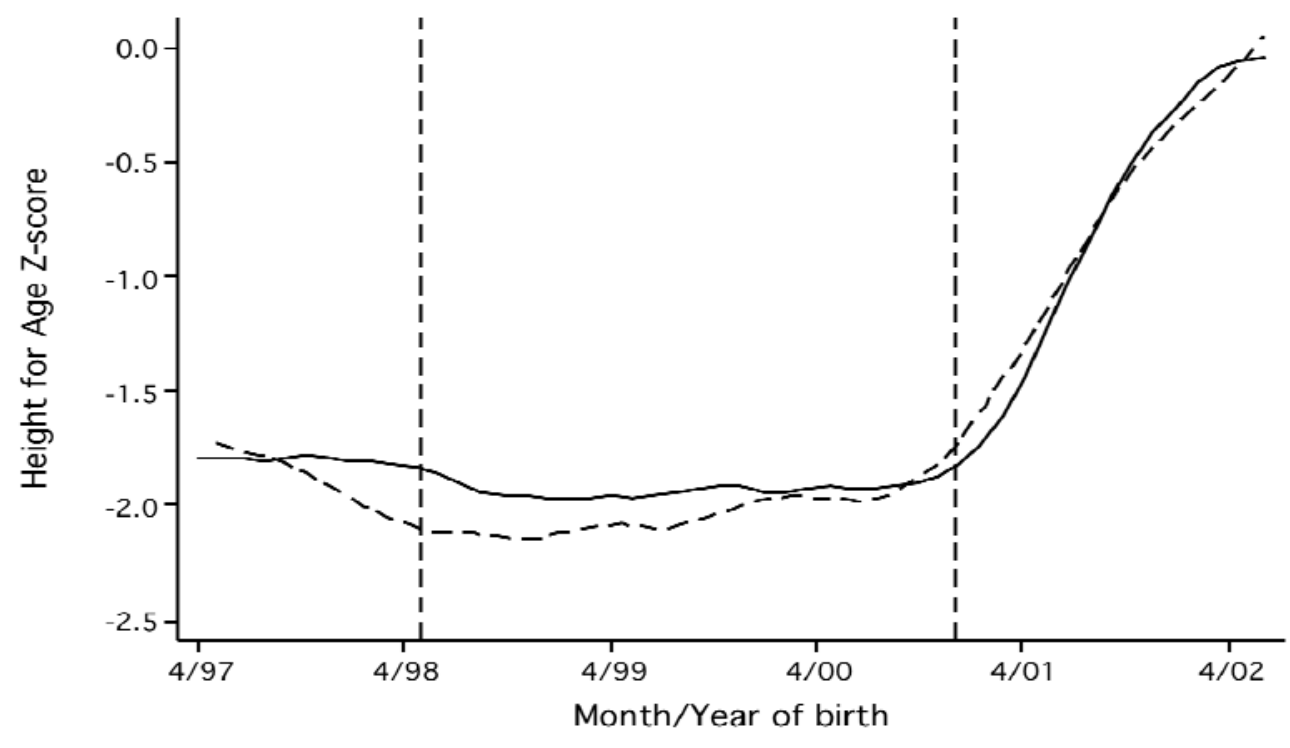

- - - War Regions Non-war Regions

Figure 3b: Height-for-age Z-scores by Month and Year of Birth and War Exposure in Eritrea in 2002, Girls Only

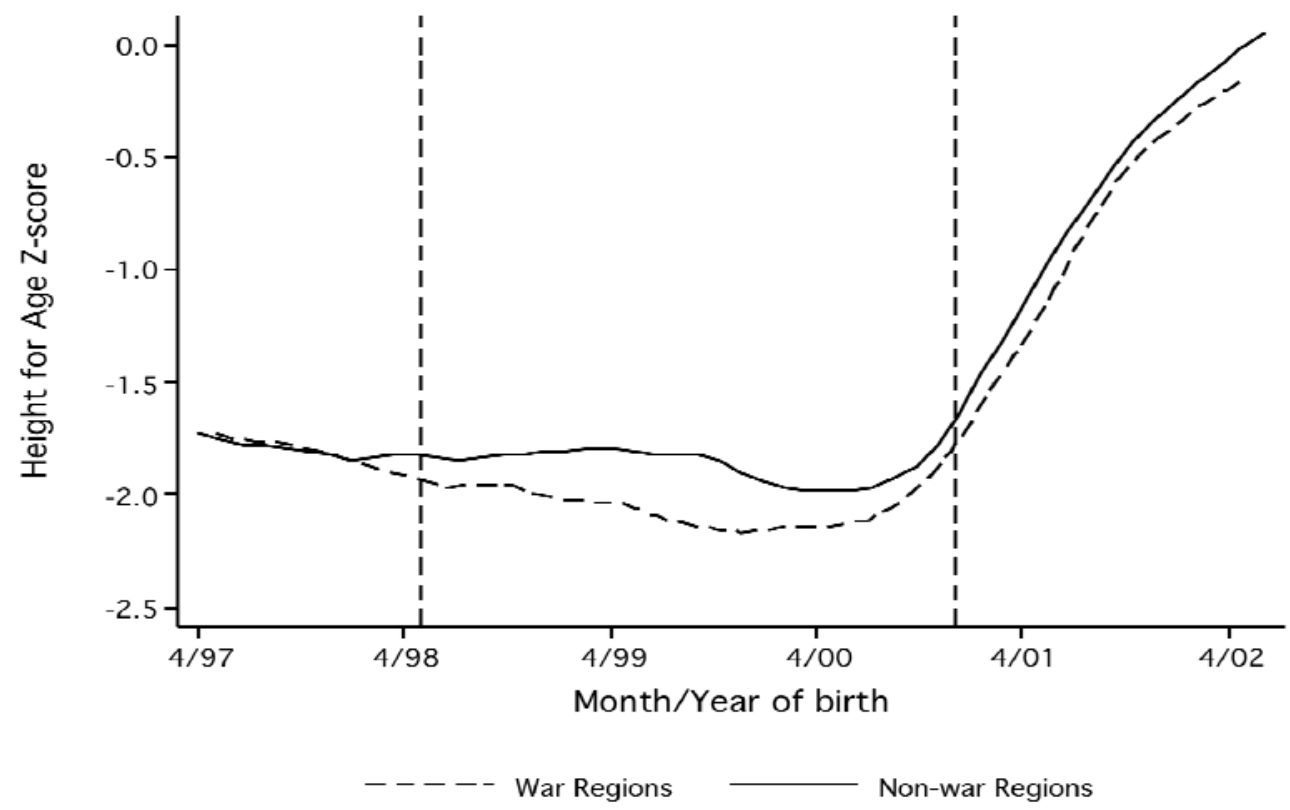

Notes: Kernel-weighted local polynomial regression (using Epanechnikov kernel) of height-for-age Z-score on month and year of birth. Dashed line indicates children living in war regions. Solid line indicates children living in non-war regions. Vertical dashed lines show the starting (May 1998) and the ending dates (December 2000) of the war. Data source: 2002 Eritrea Demographic and Health Survey. 
Figure 4a: Height-for-age Z-scores by Month and Year of Birth and by War Exposure in Ethiopia in 2000, Boys Only

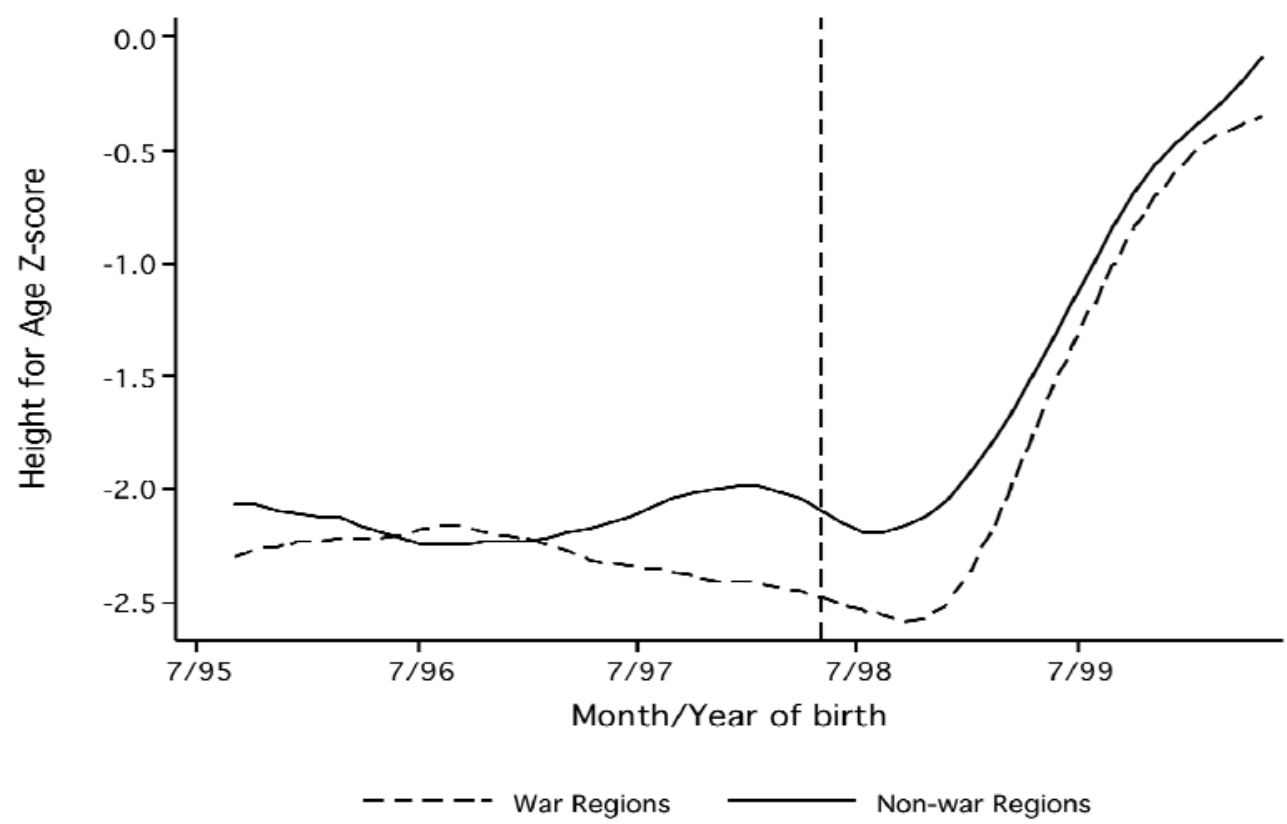

Figure 4b: Height-for-age Z-scores by Month and Year of Birth and by War Exposure in Ethiopia in 2000, Girls Only

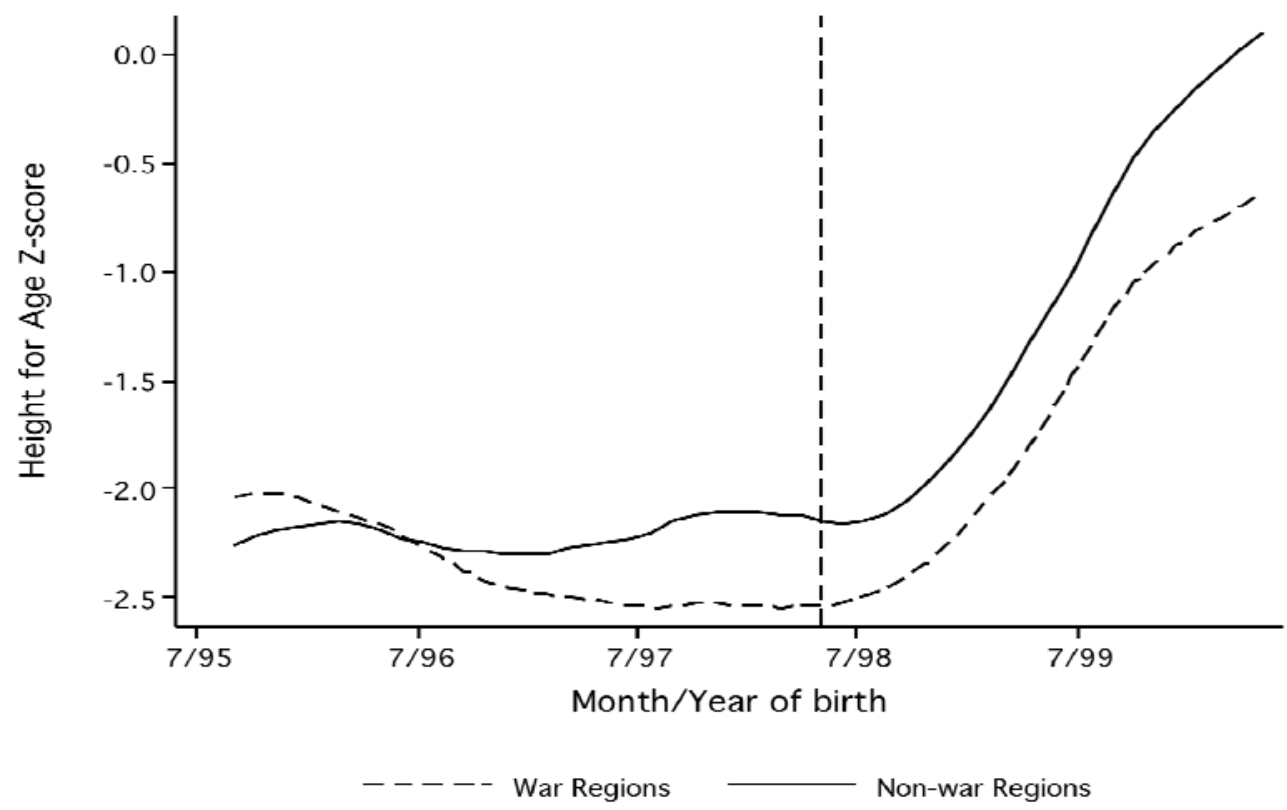

Note: Kernel-weighted local polynomial regression (using Epanechnikov kernel) of height-for-age Z-score on month and year of birth. Dashed line indicates children living in war regions. Solid line indicates children living in non-war regions. Vertical dashed line shows the starting date (May 1998) of the war. Data source: 2000 Ethiopia Demographic and Health Survey. 
Table 1: Child Characteristics, by Exposure to the War

\begin{tabular}{|c|c|c|c|c|c|c|}
\hline & \multicolumn{3}{|c|}{ Eritrea (Year 2002) } & \multicolumn{3}{|c|}{ Ethiopia (Year 2000 and 2005) } \\
\hline & $\begin{array}{c}\text { Exposed } \\
{[1]} \\
\end{array}$ & $\begin{array}{c}\text { Non- } \\
\text { exposed } \\
{[2]}\end{array}$ & $\begin{array}{c}\text { Difference } \\
{[3]} \\
\end{array}$ & $\begin{array}{c}\text { Exposed } \\
{[4]} \\
\end{array}$ & $\begin{array}{c}\text { Non- } \\
\text { exposed } \\
{[5]}\end{array}$ & $\begin{array}{c}\text { Difference } \\
{[6]}\end{array}$ \\
\hline \multicolumn{7}{|l|}{ Panel A: Child Characteristics } \\
\hline Height-for-age Z-score & $\begin{array}{l}-2.005 \\
{[0.040]}\end{array}$ & $\begin{array}{c}-1.325 \\
{[0.045]}\end{array}$ & $\begin{array}{l}-0.680 * * * \\
{[0.057]}\end{array}$ & $\begin{array}{c}-2.072 \\
{[0.056]}\end{array}$ & $\begin{array}{c}-1.732 \\
{[0.025]}\end{array}$ & $\begin{array}{c}-0.341^{* * *} \\
{[0.061]}\end{array}$ \\
\hline Proportion Stunted & $\begin{array}{c}0.516 \\
{[0.013]}\end{array}$ & $\begin{array}{r}0.330 \\
{[0.013]}\end{array}$ & $\begin{array}{l}0.186 * * * \\
{[0.018]}\end{array}$ & $\begin{array}{c}0.532 \\
{[0.016]}\end{array}$ & $\begin{array}{c}0.441 \\
{[0.007]}\end{array}$ & $\begin{array}{c}0.091 * * * \\
{[0.017]}\end{array}$ \\
\hline Proportion Severely Stunted & $\begin{array}{c}0.234 \\
{[0.011]}\end{array}$ & $\begin{array}{r}0.143 \\
{[0.009]}\end{array}$ & $\begin{array}{l}0.091 * * * \\
{[0.014]}\end{array}$ & $\begin{array}{c}0.267 \\
{[0.015]}\end{array}$ & $\begin{array}{c}0.221 \\
{[0.005]}\end{array}$ & $\begin{array}{c}0.046^{* * *} \\
{[0.016]}\end{array}$ \\
\hline Male & $\begin{array}{c}0.528 \\
{[0.011]}\end{array}$ & $\begin{array}{r}0.515 \\
{[0.008]}\end{array}$ & $\begin{array}{c}0.013 \\
{[0.014]}\end{array}$ & $\begin{array}{c}0.490 \\
{[0.013]}\end{array}$ & $\begin{array}{c}0.509 \\
{[0.005]}\end{array}$ & $\begin{array}{c}-0.019 \\
{[0.014]}\end{array}$ \\
\hline Age in Months & $\begin{array}{c}39.284 \\
{[0.249]}\end{array}$ & $\begin{array}{l}24.263 \\
{[0.521]}\end{array}$ & $\begin{array}{l}15.020^{* * *} \\
{[0.586]}\end{array}$ & $\begin{array}{l}27.940 \\
{[0.324]}\end{array}$ & $\begin{array}{l}26.747 \\
{[0.138]}\end{array}$ & $\begin{array}{c}1.193^{* * *} \\
{[0.347]}\end{array}$ \\
\hline \multicolumn{7}{|c|}{ Panel B: Height for Age Z-score by Age in Months } \\
\hline Age $<=24$ Months & $\begin{array}{l}-2.106 \\
{[0.085]}\end{array}$ & $\begin{array}{c}-0.896 \\
{[0.043]}\end{array}$ & $\begin{array}{l}-1.210^{* * *} \\
{[0.089]}\end{array}$ & $\begin{array}{c}-1.751 \\
{[0.083]}\end{array}$ & $\begin{array}{c}-1.337 \\
{[0.032]}\end{array}$ & $\begin{array}{c}-0.414^{* * *} \\
{[0.088]}\end{array}$ \\
\hline Age $>24$ Months & $\begin{array}{l}-1.988 \\
{[0.042]} \\
\end{array}$ & $\begin{array}{c}-1.856 \\
{[0.059]} \\
\end{array}$ & $\begin{array}{l}-0.132 * \\
{[0.073]} \\
\end{array}$ & $\begin{array}{c}-2.296 \\
{[0.060]} \\
\end{array}$ & $\begin{array}{c}-2.063 \\
{[0.029]} \\
\end{array}$ & $\begin{array}{c}-0.233^{* * *} \\
{[0.065]}\end{array}$ \\
\hline Observations & 1,878 & 3,463 & & 1,300 & 10,042 & \\
\hline \multicolumn{7}{|c|}{$\begin{array}{l}\text { Notes: Robust standard errors in brackets, clustered at the enumeration level. * significant at } 10 \%, * * \\
\text { significant at } 5 \% \text {, and } * * * \text { significant at } 1 \% \text {. "Exposed" indicates a child living in a region that } \\
\text { experienced war and who was born before or during the war. "Non-exposed" indicates a child living in a } \\
\text { region that did not experience conflict or a child who was born in a war region after the war ended. } \\
\text { Children with a height-for-age Z-score below }-2 \text { are considered stunted, while children with a height-for- } \\
\text { age Z-score below -3 are considered severely stunted. Data source: } 2002 \text { Eritrea and } 2000 \text { and } 2005 \\
\text { Ethiopia Demographic and Health Surveys. }\end{array}$} \\
\hline
\end{tabular}


Table 2: Measuring the Impact of War Exposure on Children's Height-for-age Z-score

\begin{tabular}{|c|c|c|c|c|c|c|}
\hline \multirow[t]{2}{*}{ Dependent Variable: Height-for-age Z-score } & \multicolumn{3}{|c|}{ Eritrea } & \multicolumn{3}{|c|}{ Ethiopia } \\
\hline & {$[1]$} & [2] & [3] & {$[4]$} & [5] & [6] \\
\hline War Region * Born During War & $\begin{array}{l}-0.244^{* * *} \\
{[0.078]}\end{array}$ & & & $\begin{array}{l}-0.588 * * * \\
{[0.112]}\end{array}$ & & \\
\hline War Region * Born Before War & $\begin{array}{c}0.023 \\
{[0.102]}\end{array}$ & & & $\begin{array}{l}-0.480^{* * * *} \\
{[0.106]}\end{array}$ & & \\
\hline Close to War Site * Born During War & & $\begin{array}{l}-0.301 * * * \\
{[0.096]}\end{array}$ & & & $\begin{array}{l}-0.471 * * * \\
{[0.147]}\end{array}$ & \\
\hline Close to War Site * Born Before War & & $\begin{array}{l}-0.031 \\
{[0.110]}\end{array}$ & & & $\begin{array}{l}-0.485^{* * *} \\
{[0.132]}\end{array}$ & \\
\hline Close to War Site & & $\begin{array}{c}0.112 \\
{[0.103]}\end{array}$ & & & $\begin{array}{c}0.124 \\
{[0.143]}\end{array}$ & \\
\hline Months of War Exposure & & & $\begin{array}{l}-0.003 \\
{[0.003]}\end{array}$ & & & $\begin{array}{l}-0.023 * * * \\
{[0.004]}\end{array}$ \\
\hline Child Age Fixed Effects & Yes & Yes & Yes & Yes & Yes & Yes \\
\hline Region Fixed Effects & Yes & Yes & Yes & Yes & Yes & Yes \\
\hline Region-Specific Time Trends & No & No & No & No & No & No \\
\hline Observations & 5,341 & 5,279 & 5,341 & 11,342 & 11,299 & 11,342 \\
\hline
\end{tabular}

Notes: Robust standard errors in brackets, clustered at the enumeration level. ${ }^{*}$ significant at $10 \%$, ** significant at $5 \%$, and $* * *$

significant at 1\%. All specifications include child age fixed effects, region fixed effects, and child gender controls. In Eritrea, the war regions are Gash Barka, Debub, and Debubawi Keyih Bahri. In Ethiopia, the war regions are Tigray and Afar. "War Region*Born During War" indicates a child living in a region affected by the war who was born during the war. "War Region*Born Before War" indicates a child living in a region affected by the war who was born before the war started. "Close to War Site*Born During War" indicates a child living within $75 \mathrm{~km}$ in Eritrea and within $125 \mathrm{~km}$ in Ethiopia from any of the three conflict sites and who was born during the war. "Close to War Site*Born Before War" indicates a child living within $75 \mathrm{~km}$ in Eritrea and within $125 \mathrm{~km}$ in Ethiopia from any of the three conflict sites and who was born before the war started. "Months of War Exposure" measures the number of months a child was alive during the war in a region affected by the war. Data source: 2002 Eritrea and 2000 and 2005 Ethiopia Demographic and Health Surveys. 
Table 3: Measuring the Impact of War Exposure on Children's Height-for-age Z-score, Including Region-Specific Time Trends

\begin{tabular}{|c|c|c|c|c|c|c|}
\hline \multirow[t]{2}{*}{ Dependent Variable: Height-for-age Z-score } & \multicolumn{3}{|c|}{ Eritrea } & \multicolumn{3}{|c|}{ Ethiopia } \\
\hline & {$[1]$} & [2] & [3] & {$[4]$} & [5] & [6] \\
\hline War Region $*$ Born During War & $\begin{array}{l}-0.385 * * * \\
{[0.112]}\end{array}$ & & & $\begin{array}{l}-0.531 * * * \\
{[0.113]}\end{array}$ & & \\
\hline War Region * Born Before War & $\begin{array}{l}-0.253 \\
{[0.191]}\end{array}$ & & & $\begin{array}{l}-0.524 * * * \\
{[0.122]}\end{array}$ & & \\
\hline Close to War Site * Born During War & & $\begin{array}{l}-0.373 * * \\
{[0.105]}\end{array}$ & & & $\begin{array}{l}-0.451 * * * \\
{[0.146]}\end{array}$ & \\
\hline Close to War Site * Born Before War & & $\begin{array}{l}-0.161 \\
{[0.135]}\end{array}$ & & & $\begin{array}{l}-0.497 * * * \\
{[0.140]}\end{array}$ & \\
\hline Close to War Site & & $\begin{array}{c}0.177 \\
{[0.112]}\end{array}$ & & & $\begin{array}{c}0.124 \\
{[0.143]}\end{array}$ & \\
\hline Months of War Exposure & & & $\begin{array}{l}-0.037 * * * \\
{[0.009]}\end{array}$ & & & $\begin{array}{l}-0.029 * * * \\
{[0.005]}\end{array}$ \\
\hline $\begin{array}{l}\text { P-value Testing Equality Between Born } \\
\text { During War and Born Before War Started }\end{array}$ & 0.277 & 0.061 & & 0.954 & 0.730 & \\
\hline Child Age Fixed Effects & Yes & Yes & Yes & Yes & Yes & Yes \\
\hline Region Fixed Effects & Yes & Yes & Yes & Yes & Yes & Yes \\
\hline Region-Specific Time Trends & Yes & Yes & Yes & Yes & Yes & Yes \\
\hline Observations & 5,341 & 5,279 & 5,341 & 11,342 & 11,299 & 11,342 \\
\hline \multicolumn{7}{|c|}{$\begin{array}{l}\text { Notes: Robust standard errors in brackets, clustered at the enumeration level. * significant at } 10 \%, * * \text { significant at } 5 \% \text {, and *** significant } \\
\text { at } 1 \% \text {. All specifications include child age fixed effects, region fixed effects, child gender controls, and region-specific time trends. In } \\
\text { Eritrea, the war regions are Gash Barka, Debub, and Debubawi Keyih Bahri. In Ethiopia, the war regions are Tigray and Afar. "War } \\
\text { Region*Born During War" indicates a child living in a region affected by the war who was born during the war. "War Region*Born Before } \\
\text { War” indicates a child living in a region affected by the war who was born before the war started. "Close to War Site*Born During War" } \\
\text { indicates a child living within } 75 \mathrm{~km} \text { in Eritrea and within } 125 \mathrm{~km} \text { in Ethiopia from any of the three conflict sites and who was born during } \\
\text { the war. "Close to War Site*Born Before War" indicates a child living within } 75 \mathrm{~km} \text { in Eritrea and within } 125 \mathrm{~km} \text { in Ethiopia from any of } \\
\text { the three conflict sites and who was born before the war started. "Months of War Exposure" measures the number of months a child was } \\
\text { alive during the war in a region affected by the war. Data source: } 2002 \text { Eritrea and } 2000 \text { and } 2005 \text { Ethiopia Demographic and Health } \\
\text { Surveys. }\end{array}$} \\
\hline
\end{tabular}


Table 4: Measuring the Impact of War Exposure on Children's Height-for-age Z-score, Boys Only

\begin{tabular}{|c|c|c|c|c|c|c|}
\hline \multirow[t]{2}{*}{ Dependent Variable: Height-for-age Z-score } & \multicolumn{3}{|c|}{ Eritrea } & \multicolumn{3}{|c|}{ Ethiopia } \\
\hline & [1] & {$[2]$} & [3] & [4] & [5] & [6] \\
\hline War Region * Born During War & $\begin{array}{l}-0.420^{* * *} \\
{[0.157]}\end{array}$ & & & $\begin{array}{l}-0.642^{* * *} \\
{[0.154]}\end{array}$ & & \\
\hline War Region * Born Before War & $\begin{array}{l}-0.308 \\
{[0.246]}\end{array}$ & & & $\begin{array}{l}-0.409 * * \\
{[0.159]}\end{array}$ & & \\
\hline Close to War Site * Born During War & & $\begin{array}{l}-0.439 * * * \\
{[0.152]}\end{array}$ & & & $\begin{array}{l}-0.601 * * * \\
{[0.182]}\end{array}$ & \\
\hline Close to War Site * Born Before War & & $\begin{array}{l}-0.202 \\
{[0.197]}\end{array}$ & & & $\begin{array}{l}-0.532 * * * \\
{[0.177]}\end{array}$ & \\
\hline Close to War Site & & $\begin{array}{c}0.221 \\
{[0.151]}\end{array}$ & & & $\begin{array}{c}0.198 \\
{[0.167]}\end{array}$ & \\
\hline Months of War Exposure & & & $\begin{array}{l}-0.050^{* * *} \\
{[0.013]}\end{array}$ & & & $\begin{array}{l}-0.027^{* * *} \\
{[0.007]}\end{array}$ \\
\hline $\begin{array}{l}\text { P-value Testing Equality Between Born } \\
\text { During War and Born Before War Started }\end{array}$ & 0.472 & 0.114 & & 0.219 & 0.705 & \\
\hline Observations & 2,775 & 2,739 & 2,775 & 5,753 & 5,731 & 5,753 \\
\hline Child Age Fixed Effects & Yes & Yes & Yes & Yes & Yes & Yes \\
\hline Region Fixed Effects & Yes & Yes & Yes & Yes & Yes & Yes \\
\hline Region-Specific Time Trends & Yes & Yes & Yes & Yes & Yes & Yes \\
\hline \multicolumn{7}{|c|}{$\begin{array}{l}\text { Notes: Robust standard errors in brackets, clustered at the enumeration level. * significant at } 10 \%, * * \text { significant at } 5 \% \text {, and } * * * \text { significant at } \\
1 \% \text {. All specifications include child age fixed effects, region fixed effects, and region-specific time trends. In Eritrea, the war regions are Gash } \\
\text { Barka, Debub, and Debubawi Keyih Bahri. In Ethiopia, the war regions are Tigray and Afar. "War Region*Born During War" indicates a } \\
\text { child living in a region affected by the war who was born during the war. "War Region*Born Before War" indicates a child living in a region } \\
\text { affected by the war who was born before the war started. "Close to War Site*Born During War" indicates a child living within } 75 \mathrm{~km} \text { in } \\
\text { Eritrea and within } 125 \mathrm{~km} \text { in Ethiopia from any of the three conflict sites and who was born during the war. "Close to War Site*Born Before } \\
\text { War” indicates a child living within } 75 \mathrm{~km} \text { in Eritrea and within } 125 \mathrm{~km} \text { in Ethiopia from any of the three conflict sites and who was born } \\
\text { before the war started. "Months of War Exposure" measures the number of months a child was alive during the war in a region affected by the } \\
\text { war. Data source: } 2002 \text { Eritrea and } 2000 \text { and } 2005 \text { Ethiopia Demographic and Health Surveys. }\end{array}$} \\
\hline
\end{tabular}


Table 5: Measuring the Impact of War Exposure on Children's Height-for-age Z-score, Girls Only

\begin{tabular}{|c|c|c|c|c|c|c|}
\hline \multirow[t]{2}{*}{ Dependent Variable: Height-for-age Z-score } & \multicolumn{3}{|c|}{ Eritrea } & \multicolumn{3}{|c|}{ Ethiopia } \\
\hline & {$[1]$} & [2] & [3] & {$[4]$} & [5] & [6] \\
\hline War Region * Born During War & $\begin{array}{l}-0.337 * * \\
{[0.161]}\end{array}$ & & & $\begin{array}{l}-0.415^{* *} \\
{[0.168]}\end{array}$ & & \\
\hline War Region * Born Before War & $\begin{array}{c}0.001 \\
{[0.284]}\end{array}$ & & & $\begin{array}{l}-0.642 * * * \\
{[0.150]}\end{array}$ & & \\
\hline Close to War Site * Born During War & & $\begin{array}{l}-0.309 * * \\
{[0.148]}\end{array}$ & & & $\begin{array}{l}-0.297 \\
{[0.204]}\end{array}$ & \\
\hline Close to War Site * Born Before War & & $\begin{array}{l}-0.133 \\
{[0.189]}\end{array}$ & & & $\begin{array}{l}-0.452^{* * *} \\
{[0.171]}\end{array}$ & \\
\hline Close to War Site & & $\begin{array}{c}0.136 \\
{[0.135]}\end{array}$ & & & $\begin{array}{c}0.026 \\
{[0.176]}\end{array}$ & \\
\hline Months of War Exposure & & & $\begin{array}{l}-0.023^{*} \\
{[0.012]}\end{array}$ & & & $\begin{array}{l}-0.031 * * * \\
{[0.006]}\end{array}$ \\
\hline $\begin{array}{l}\text { P-value Testing Equality Between Born } \\
\text { During War and Born Before War Started }\end{array}$ & 0.345 & 0.339 & & 0.213 & 0.416 & \\
\hline Observations & 2,566 & 2,540 & 2,566 & 5,589 & 5,568 & 5,589 \\
\hline Child Age Fixed Effects & Yes & Yes & Yes & Yes & Yes & Yes \\
\hline Region Fixed Effects & Yes & Yes & Yes & Yes & Yes & Yes \\
\hline Region-Specific Time Trends & Yes & Yes & Yes & Yes & Yes & Yes \\
\hline \multicolumn{7}{|c|}{$\begin{array}{l}\text { Notes: Robust standard errors in brackets, clustered at the enumeration level. * significant at } 10 \%,{ }^{* *} \text { significant at } 5 \% \text {, and } * * * \text { significant at } \\
1 \% \text {. All specifications include child age fixed effects, region fixed effects, and region-specific time trends. In Eritrea, the war regions are Gash } \\
\text { Barka, Debub, and Debubawi Keyih Bahri. In Ethiopia, the war regions are Tigray and Afar. "War Region*Born During War" indicates a } \\
\text { child living in a region affected by the war who was born during the war. "War Region*Born Before War" indicates a child living in a region } \\
\text { affected by the war who was born before the war started. "Close to War Site*Born During War" indicates a child living within } 75 \mathrm{~km} \text { in } \\
\text { Eritrea and within } 125 \mathrm{~km} \text { in Ethiopia from any of the three conflict sites and who was born during the war. "Close to War Site*Born Before } \\
\text { War" indicates a child living within } 75 \mathrm{~km} \text { in Eritrea and within } 125 \mathrm{~km} \text { in Ethiopia from any of the three conflict sites and who was born } \\
\text { before the war started. "Months of War Exposure" measures the number of months a child was alive during the war in a region affected by the } \\
\text { war. Data source: } 2002 \text { Eritrea and } 2000 \text { and } 2005 \text { Ethiopia Demographic and Health Surveys. }\end{array}$} \\
\hline
\end{tabular}


Table 6: OLS Estimation (Using War Intensity) and IV Estimation (Using Close to War Site as an Instrument) Measuring the Impact of War Exposure on Children's Height-for-age Z-score

\begin{tabular}{lcc}
\hline Dependent Variable: Height-for-age Z-score & $\begin{array}{c}\text { Eritrea } \\
{[1]}\end{array}$ & $\begin{array}{c}\text { Ethiopia } \\
{[2]}\end{array}$ \\
\hline Panel A: OLS estimation & & \\
War Intensity * Born During War & $-0.023^{* * *}$ & $-0.018^{* * *}$ \\
& {$[0.008]$} & {$[0.005]$} \\
War Intensity * Born Before War & -0.022 & $-0.021^{* * *}$ \\
& {$[0.014]$} & {$[0.005]$} \\
& & \\
\hline Panel B: IV estimation & & \\
War Intensity * Born During War & $-0.068^{* * *}$ & $-0.019^{* *}$ \\
& {$[0.025]$} & {$[0.007]$} \\
War Intensity * Born Before War & $-0.073^{*}$ & $-0.025^{* * *}$ \\
& {$[0.044]$} & {$[0.007]$} \\
& & \\
\hline Child Age Fixed Effects & Yes & Yes \\
Region Fixed Effects & Yes & Yes \\
Region-Specific Time Trend & Yes & Yes \\
\hline F-statistic of Excluded Instruments: & & \\
1. War Intensity * Born During War & 41.799 & 150.790 \\
2. War Intensity * Born Before War & 38.561 & 153.871 \\
\hline Observations & 5,279 & 11,299 \\
\hline Notes: Robust stans & &
\end{tabular}

Notes: Robust standard errors in brackets, clustered at the enumeration level. * significant at $10 \%, * *$ significant at $5 \%$, and $* * *$ significant at $1 \%$. All specifications include child age fixed effects, region fixed effects, child gender controls, and region-specific time trends. "War Intensity” indicates for each region the number of internally displaced individuals/10,000. Displacement data for Eritrea and Ethiopia come from the United Nations Office for the Coordination of Humanitarian Affairs (UN OCHA). IV estimation in Panel B uses the "Close to War Site" variable as an instrument for the potentially endogenous "War Intensity" variable. Testing for weak instruments using the Kleibergen-Paap test yields a test statistic for the Eritrea IV regression of 24.78 and for the Ethiopia IV regression of 42.22 suggesting the instruments are strong. Data source: 2002 Eritrea and 2000 and 2005 Ethiopia Demographic and Health Surveys. 
Table 7: Measuring the Impact of War Exposure on Children's Height-for-age Z-score, By Residency Status

\begin{tabular}{|c|c|c|c|c|}
\hline \multirow{2}{*}{$\begin{array}{l}\text { Dependent Variable: } \\
\text { Height-for-age Z-score }\end{array}$} & \multicolumn{2}{|c|}{ Eritrea } & \multicolumn{2}{|c|}{ Ethiopia } \\
\hline & $\begin{array}{c}\text { 1st } \\
\text { Definition } \\
{[1]}\end{array}$ & $\begin{array}{c}\text { 2nd } \\
\text { Definition } \\
{[2]}\end{array}$ & $\begin{array}{c}\text { 1st } \\
\text { Definition } \\
{[3]}\end{array}$ & $\begin{array}{c}\text { 2nd } \\
\text { Definition } \\
{[4]}\end{array}$ \\
\hline \multicolumn{5}{|l|}{ Panel A: Difference-in-Differences } \\
\hline War Region * Born During War & $\begin{array}{l}-0.383^{* * *} \\
{[0.114]}\end{array}$ & $\begin{array}{l}-0.386 * * * \\
{[0.118]}\end{array}$ & $\begin{array}{c}-0.550 * * * \\
{[0.115]}\end{array}$ & $\begin{array}{l}-0.526 * * * \\
{[0.107]}\end{array}$ \\
\hline War Region * Born Before War & $\begin{array}{l}-0.254 \\
{[0.194]}\end{array}$ & $\begin{array}{l}-0.259 \\
{[0.197]}\end{array}$ & $\begin{array}{c}-0.547 * * * \\
{[0.122]} \\
\end{array}$ & $\begin{array}{l}-0.625 * * * \\
{[0.122]} \\
\end{array}$ \\
\hline \multicolumn{5}{|l|}{ Panel B: War Intensity (OLS) } \\
\hline War Intensity * Born During War & $\begin{array}{l}-0.024 * * * \\
{[0.008]}\end{array}$ & $\begin{array}{l}-0.024 * * * \\
{[0.008]}\end{array}$ & $\begin{array}{c}-0.019 * * * \\
{[0.005]}\end{array}$ & $\begin{array}{l}-0.016^{* * *} \\
{[0.005]}\end{array}$ \\
\hline War Intensity * Born Before War & $\begin{array}{l}-0.019 \\
{[0.014]}\end{array}$ & $\begin{array}{l}-0.019 \\
{[0.014]}\end{array}$ & $\begin{array}{c}-0.022 * * * \\
{[0.005]}\end{array}$ & $\begin{array}{l}-0.023 * * * \\
{[0.005]}\end{array}$ \\
\hline \multicolumn{5}{|l|}{ Panel C: War Intensity (IV) } \\
\hline War Intensity * Born During War & $\begin{array}{l}-0.064 * * \\
{[0.026]}\end{array}$ & $\begin{array}{l}-0.070 * * * \\
{[0.025]}\end{array}$ & $\begin{array}{l}-0.019 * * \\
{[0.007]}\end{array}$ & $\begin{array}{l}-0.015^{* *} \\
{[0.007]}\end{array}$ \\
\hline War Intensity * Born Before War & $\begin{array}{l}-0.065 \\
{[0.045]}\end{array}$ & $\begin{array}{l}-0.073^{*} \\
{[0.044]}\end{array}$ & $\begin{array}{c}-0.026^{* * *} \\
{[0.007]}\end{array}$ & $\begin{array}{l}-0.027 * * * \\
{[0.006]}\end{array}$ \\
\hline Child Age Fixed Effects & Yes & Yes & Yes & Yes \\
\hline Region Fixed Effects & Yes & Yes & Yes & Yes \\
\hline Region-Specific Time Trends & Yes & Yes & Yes & Yes \\
\hline Observations & 5,032 & 4,886 & 11,032 & 11,010 \\
\hline \multicolumn{5}{|c|}{$\begin{array}{l}\text { Notes: Robust standard errors in brackets, clustered at the enumeration level. * significant at } 10 \%, * * \\
\text { significant at } 5 \% \text {, and } * * * \text { significant at } 1 \% \text {. All specifications include child age fixed effects, region } \\
\text { fixed effects, child gender controls, and region-specific time trends. Columns } 1 \text { and } 3 \text { restrict the } \\
\text { previous sample of children to now only include children born in their current place of residence. } \\
\text { Columns } 2 \text { and } 4 \text { further restrict the sample to only include those children who were born in their current } \\
\text { place of residence and whose families lived in their current place of residence during the war. "War } \\
\text { Region*Born During War" indicates a child living in a region affected by the war who was born during } \\
\text { the war. "War Region*Born Before War" indicates a child living in a region affected by the war who was } \\
\text { born before the war started. "War Intensity" indicates for each region the number of internally displaced } \\
\text { individuals/10,000. Displacement data for Eritrea and Ethiopia come from the United Nations Office for } \\
\text { the Coordination of Humanitarian Affairs (UN OCHA). IV estimation in Panel C uses the "Close to War } \\
\text { Site” variable as an instrument for the potentially endogenous "War Intensity” variable. Testing for weak } \\
\text { instruments using the Kleibergen-Paap test yields a test statistic for the Eritrea IV regressions in columns } \\
1 \text { and } 2 \text { of } 25.57 \text { and } 24.15 \text { and for the Ethiopia IV regressions in columns } 3 \text { and } 4 \text { of } 44.10 \text { and } 76.84 \\
\text { suggesting the instruments are strong. Data source: } 2002 \text { Eritrea and } 2000 \text { and } 2005 \text { Ethiopia } \\
\text { Demographic and Health Surveys. }\end{array}$} \\
\hline
\end{tabular}


Table 8: Comparing the Impact in Eritrea and Ethiopia of War Exposure on Children's Height-for-age Z-score

\begin{tabular}{|c|c|c|c|}
\hline Dependent Variable: Height-for-age Z-score & $\begin{array}{c}\text { Differences- } \\
\text { in-Differences } \\
{[1]} \\
\end{array}$ & $\begin{array}{c}\text { War Intensity } \\
\text { (OLS) } \\
{[2]} \\
\end{array}$ & $\begin{array}{c}\text { War Intensity } \\
\text { (IV) } \\
{[3]} \\
\end{array}$ \\
\hline \multicolumn{4}{|l|}{ Panel A: Difference-in-Differences } \\
\hline \multirow[t]{2}{*}{ [a] War Region * Born During War } & $-0.426 * * *$ & & \\
\hline & [0.108] & & \\
\hline \multirow[t]{2}{*}{ [b] War Region * Born During War * Ethiopia } & -0.109 & & \\
\hline & [0.158] & & \\
\hline \multirow{2}{*}{ [c] War Region * Born Before War } & $-0.367 * *$ & & \\
\hline & {$[0.178]$} & & \\
\hline \multirow[t]{2}{*}{ [d] War Region * Born Before War * Ethiopia } & -0.152 & & \\
\hline & [0.216] & & \\
\hline \multicolumn{4}{|l|}{ Panel B: War Intensity } \\
\hline \multirow[t]{2}{*}{ [a] War Intensity * Born During War } & & $-0.027 * * *$ & $-0.069 * * *$ \\
\hline & & {$[0.008]$} & [0.023] \\
\hline \multirow[t]{2}{*}{ [b] War Intensity * Born During War * Ethiopia } & & 0.008 & $0.050 * *$ \\
\hline & & [0.009] & {$[0.024]$} \\
\hline \multirow[t]{2}{*}{ [c] War Intensity * Born Before War } & & $-0.028 * *$ & $-0.080 * *$ \\
\hline & & [0.013] & {$[0.038]$} \\
\hline \multirow[t]{2}{*}{ [d] War Intensity * Born Before War * Ethiopia } & & 0.007 & 0.055 \\
\hline & & [0.014] & [0.039] \\
\hline P-value of $[\mathrm{a}]+[\mathrm{b}]=0$ & 0.000 & 0.000 & 0.010 \\
\hline P-value of $[c]+[d]=0$ & 0.000 & 0.000 & 0.000 \\
\hline Child Age Fixed Effects & Yes & Yes & Yes \\
\hline Region Fixed Effects & Yes & Yes & Yes \\
\hline Region-Specific Time Trends & Yes & Yes & Yes \\
\hline Observations & 16,683 & 16,578 & 16,578 \\
\hline \multicolumn{4}{|c|}{$\begin{array}{l}\text { Notes: Robust standard errors in brackets, clustered at the enumeration level. * significant at } 10 \%, * * \\
\text { significant at } 5 \% \text {, and } * * * \text { significant at } 1 \% \text {. All specifications include child age fixed effects, region } \\
\text { fixed effects, child gender controls, and region-specific time trends. "War Region*Born During War" } \\
\text { indicates a child living in a region affected by the war who was born during the war. "War Region*Born } \\
\text { Before War" indicates a child living in a region affected by the war who was born before the war } \\
\text { started. "War Intensity" indicates for each region the number of internally displaced individuals/10,000. } \\
\text { Displacement data for Eritrea and Ethiopia come from the United Nations Office for the Coordination of } \\
\text { Humanitarian Affairs (UN OCHA). IV estimation in Panel C uses the "Close to War Site" variable as an } \\
\text { instrument for the potentially endogenous "War Intensity" variable. Testing for weak instruments using } \\
\text { the Kleibergen-Paap test yields a test statistic in column } 3 \text { of } 13.95 \text { suggesting the instruments are } \\
\text { strong. Data source: } 2002 \text { Eritrea and } 2000 \text { and } 2005 \text { Ethiopia Demographic and Health Surveys. }\end{array}$} \\
\hline
\end{tabular}

